\title{
Expert consensus on the diagnosis and treatment of thrombocytopenia in adult critical care patients in China
}

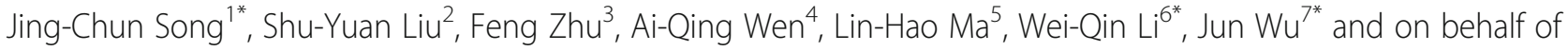 \\ the Critical Care Medicine Committee of Chinese People's Liberation Army (PLA); Chinese Society of Laboratory \\ Medicine, Chinese Medical Association
}

\begin{abstract}
Thrombocytopenia is a common complication of critical care patients. The rates of bleeding events and mortality are also significantly increased in critical care patients with thrombocytopenia. Therefore, the Critical Care Medicine Committee of Chinese People's Liberation Army (PLA) worked with Chinese Society of Laboratory Medicine, Chinese Medical Association to develop this consensus to provide guidance for clinical practice. The consensus includes five sections and 27 items: the definition of thrombocytopenia, etiology and pathophysiology, diagnosis and differential diagnosis, treatment and prevention.
\end{abstract}

Keywords: Thrombocytopenia, Adult, Critical care, Diagnosis, Treatment, Expert consensus

\section{Background}

Platelets are blood cells directly involved in clotting and inflammatory regulation, and thrombocytopenia is a common complication of critical care patients [1]. Statistics show that the incidence of thrombocytopenia is 8.3 to $67.6 \%$ in adult critical care patients admitted to the Intensive Care Unit (ICU) and 14 to $44 \%$ during ICU stays [2]. The rates of bleeding events, blood transfusions and even mortality are also significantly increased in critical care patients with thrombocytopenia [3-5]. Therefore, the Critical Care Medicine Committee of Chinese People's Liberation Army (PLA) worked with Chinese Society of Laboratory Medicine, Chinese

\footnotetext{
*Correspondence: songjingchun@126.com; liweiqindr@vip.163.com; wujunpostbox@sina.com

${ }^{1}$ Department of Critical Care Medicine, the 908th Hospital of Joint Logistics Support Forces of Chinese PLA, Nanchang 360104, China

${ }^{6}$ Surgery Intensive Care Unit, Jinling Hospital, Medical School of Nanjing University, Nanjing 210002, China

${ }^{7}$ Department of Clinical Laboratory, Peking University Fourth School of Clinical Medicine, Beijing Jishuitan Hospital, Beijing 100035, China

Full list of author information is available at the end of the article
}

Medical Association to develop this consensus to provide guidance for clinical practice.

In August 2019, an expert consensus writing committee was formed by members from the Critical Care Medicine Committee of the Chinese PLA and the Chinese Society of Laboratory Medicine, Chinese Medical Association. After discussion, the committee decided that the consensus would include five sections and 27 items: the definition of thrombocytopenia, etiology and pathophysiology, diagnosis and differential diagnosis, treatment, and prevention (Fig. 1). Based on recent developments in critical care medicine, laboratory medicine, and blood transfusion medicine, the committee members met to review and discuss the content in November2019, and each speaker's comments and recommendations were documented. After the meeting, the consensus was revised to reflect each expert's inputs and was finalized after several conference calls and discussions. 

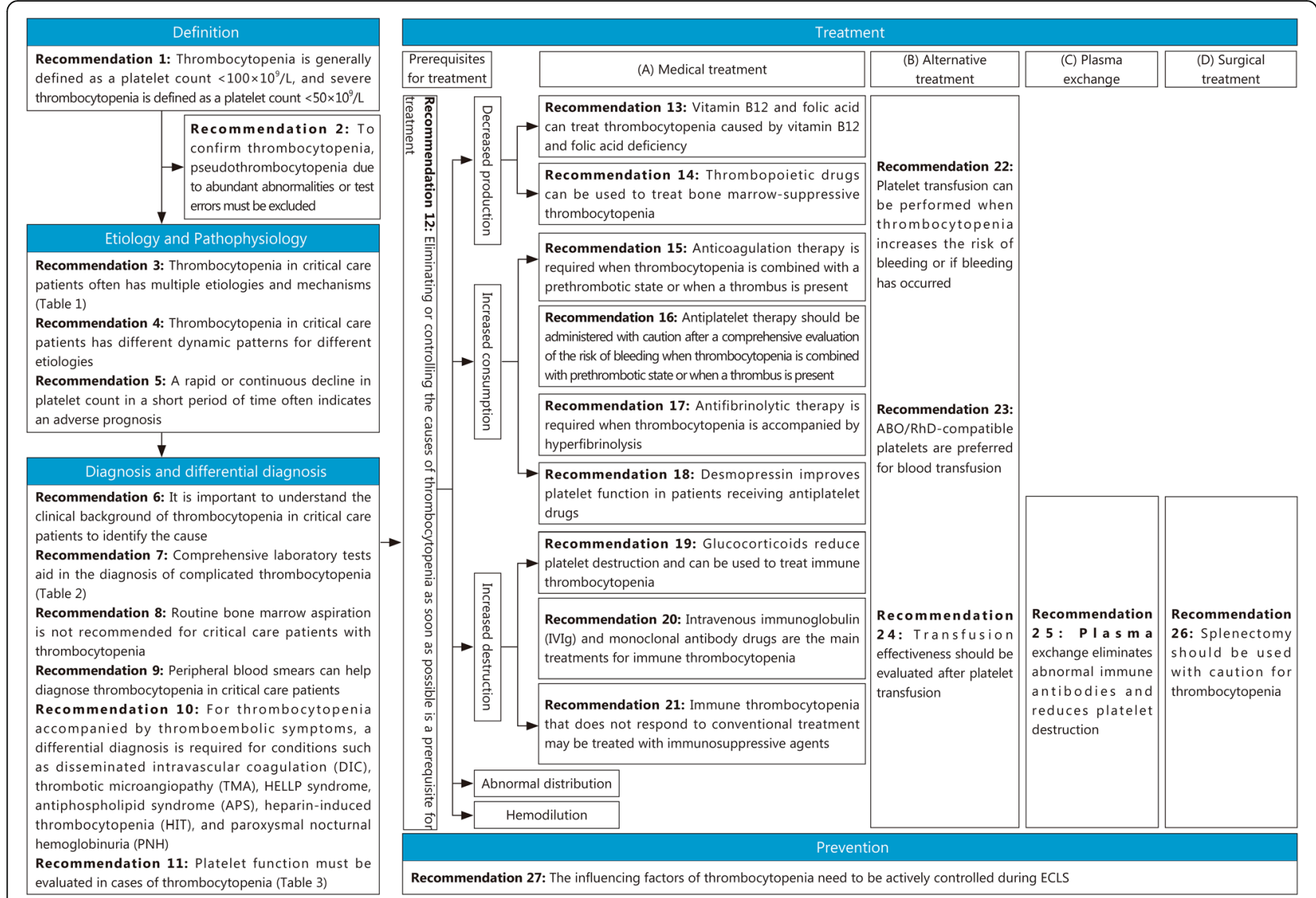

Fig. 1 Key points of the Expert consensus on the diagnosis and treatment of thrombocytopenia in adult critical care patients in China

\section{Definition}

Recommendation 1: Thrombocytopenia is generally defined as a platelet count $<100 \times 10^{9} / \mathrm{L}$, and severe thrombocytopenia is defined as a platelet count $<50 \times 10^{9} / \mathrm{L}$ In healthy individuals, megakaryocytes in the bone marrow produce approximately $150 \times 10^{6}$ platelets per day. The life span of platelets is approximately 10 days. The range of platelet counts in the normal population varies with age, sex, and ethnicity. In 2012, the former Ministry of Health of China issued Blood Cell Analysis: Reference Ranges as the health industry standard; it defines the normal range of platelet count as 125 to $350 \times 10^{9} / \mathrm{L}$. [6] Thrombocytopenia may be absolute or relative depending on the rate of decline in platelet count. In Europe and the US, absolute thrombocytopenia is usually defined as a platelet count $<150 \times 10^{9} / \mathrm{L}$. The normal platelet count range is usually lower in the Chinese population than in European and US populations; therefore, this consensus recommends that for Chinese adult critical care patients, absolute thrombocytopenia should be defined as a platelet count $<100 \times 10^{9} / \mathrm{L}[7,8]$, and relative thrombocytopenia should be defined as a platelet count decline of $30 \%$ or more from the baseline level.

\section{Recommendation 2: To confirm thrombocytopenia, pseudothrombocytopenia due to sample abnormalities or test errors must be excluded}

Platelet count refers to the number of platelets in a unit volume of blood. The main test methods include blood analysis, microscopic counts, and flow cytometry. Blood analysis is the main screening method as it is fast, repeatable, and accurate. The accuracy of a platelet count is subject to sample collection, transportation, storage, and testing. Poor blood flow during blood collection can easily destroy platelets. Prolonged storage or low temperature can activate platelets and lead to pseudothrombocytopenia. The diameter of normal platelets is approximately 1.5 to $3 \mu \mathrm{m}$; for giant platelets, which are commonly seen in Bernard-Soulier syndrome, Glanzmann thrombasthenia, and myelodysplastic syndrome (MDS), the diameter is $>7 \mu \mathrm{m}$. The blood analyzer usually counts cells based on cell size, making it prone to errors in identifying giant platelets and subsequently in diagnosing pseudothrombocytopenia. The anticoagulant ethylenediaminetetraacetic acid (EDTA) in the tube can chelate with calcium in the blood, leading to conformational changes in the platelet membrane 
glycoprotein receptorIIb/IIIa, which induces platelet aggregation [9]. The blood analyzer can mistake aggregated platelets for white or red blood cells, leading to a diagnosis of pseudothrombocytopenia. Such cases can be differentiated with blood smears and microscopic counts [10].

\section{Etiology and pathophysiology}

Recommendation 3: Thrombocytopenia in critical care patients often has multiple etiologies and mechanisms

For critical care patients, thrombocytopenia can be primary or acquired. Primary thrombocytopenia is usually a result of hematological diseases, whereas acquired thrombocytopenia is more complex and may be caused by many conditions such as infection, injury, immune disorders, and nutritional disorders. Thrombocytopeniais associated with five pathophysiology mechanisms: decreased production, increased consumption, increased destruction, abnormal distribution, and hemodilution (Table 1) [7, 11, 12]. Decreased platelet production is often caused by hematological diseases, lack of nutrient substrates, or bone marrow suppression. Under normal conditions, platelets are cleared by the monocytes/macrophages of the reticuloendothelial system. In cases of immune disorders, antiplatelet autoantibodies bind to platelets and megakaryocytes, leading to increased destruction of platelets by the reticular endothelial system and subsequently to thrombocytopenia. In cases of major bleeding or extensive thrombosis, excessive consumption of platelets also leads to thrombocytopenia. Moreover, massive rehydration and blood transfusion can cause hemodilution and thrombocytopenia. Abnormal distribution is more common in spleen-related conditions and hypothermia. Under normal conditions, one-third of platelets are stored in the spleen. In the case of splenomegaly and increased spleen congestion, platelets are redistributed throughout the body, resulting in more platelets in the spleen and a decrease in circulating platelets. A condition may cause thrombocytopenia through two or more mechanisms. For example, chronic liver disease reduces platelet production due to bone marrow suppression and forms autoantibodies that lead to increased platelet destruction [13]. In addition, a patient may have two or more conditions that cause thrombocytopenia, making an accurate diagnosis more challenging $[14,15]$.

Several studies of ICU patients with thrombocytopenia have shown that the causes of thrombocytopenia in critical care patients include (from more to less common) sepsis, DIC, dilution-induced thrombocytopenia, folic acid deficiency, malignant tumors, and drug-induced thrombocytopenia [12]. Sepsis is the most common cause of thrombocytopenia in ICU patients. Absolute thrombocytopenia is often associated with three or more mechanisms, and relative thrombocytopenia is often associated with two mechanisms.

\section{Recommendation 4: Thrombocytopenia in critical care patients has different dynamic patterns for different etiologies}

The dynamic patterns of thrombocytopenia are related to the characteristics of the disease. Therefore, identifying the patterns of thrombocytopenia helps to determine the cause of thrombocytopenia. Conversely, identifying the platelet count patterns of various diseases also helps to predict thrombocytopenia trends. For example, after major surgeries such as hip replacement, abdominal surgery, and cardiac surgery, platelet count usually reaches its nadir between day 1 and day 4 after operation due to tissue damage and blood loss, recovers to its preoperation level between day 5 and day 7 , and peaks by day 14 after surgery $[16,17]$. This pattern is related to increased thrombopoietin due to acute thrombocytopenia, and it usually takes 3 days for thrombopoietin to promote the proliferation of megakaryocytes and their division into platelets [18]. For patients with severe trauma, platelet count can decrease at $2 \mathrm{~h}$ after admission, and the risk of bleeding and mortality increases if the platelet count continues to decrease at the rate of $1 \times 10^{9} / \mathrm{L} / \mathrm{h}$ in the following $22 \mathrm{~h} \mathrm{[19].} \mathrm{For} \mathrm{sepsis} \mathrm{patients,} \mathrm{the} \mathrm{platelet}$ count decreases to $<150 \times 10^{9} / \mathrm{L}$ within 3 days after ICU admission in $40 \%$ of patients and to $<150 \times 10^{9} /$ $\mathrm{L}$ within 5 days after ICU admission in $90 \%$ of patients, However, the platelet count can recover to its normal level within 5 days if the underlying disease is effectively controlled [20].

\section{Recommendation 5: A rapid or continuous decline in platelet count over a short period often indicates an adverse prognosis}

The timing, rate, and duration of thrombocytopenia and its clinical implications vary in critical care patients. A rapid or continuous decline in platelet counts over a short period often indicates acute platelet disorder and an adverse prognosis, which requires clinicians to actively identify the cause and implement interventions as early as possible $[5,21]$. Past studies showed that mortality and complication rates were significantly increased in critical care patients if platelet count recovery took more than 4 days [22]. For example, Akca et al. [23] showed that the mortality rate was up to $66 \%$ in critical care patients if thrombocytopenia persisted for 14 days after ICU admission, whereas the mortality rate was only $16 \%$ if the platelet count recovered to its normal level or higher. In addition, the recovery rate helps to evaluate prognosis. Statistics show that for critical care patients with thrombocytopenia, the platelet count increases by 
Table 1 Common causes of thrombocytopenia in critical care patients

\begin{tabular}{|c|c|c|}
\hline Type & & Common causes \\
\hline \multirow{9}{*}{$\begin{array}{l}\text { Decreased platelet } \\
\text { production }\end{array}$} & \multirow{6}{*}{ Bone marrow suppression } & Severe infections (bacteria, viruses, fungi, parasites, etc.) \\
\hline & & Drugs such as valproic acid, daptomycin, linezolid, and interferon \\
\hline & & Poisoning, such as ethanol \\
\hline & & Chemotherapy drugs \\
\hline & & Radiation therapy \\
\hline & & Chronic liver disease \\
\hline & \multirow[t]{2}{*}{ Lack of nutrient substrates } & Folic acid and vitamin B12 deficiency \\
\hline & & Pregnancy \\
\hline & Hematological diseases & Leukemia, aplastic anemia (AA) \\
\hline \multirow{21}{*}{$\begin{array}{l}\text { Increased platelet } \\
\text { consumption }\end{array}$} & Bleeding & Traumatic coagulopathy, major gastrointestinal bleeding, cerebral hemorrhage \\
\hline & Severe infection & $\begin{array}{l}\text { Infections with bacteria (such as Helicobacter pylori), viruses, fungi, parasites, rickettsia, and } \\
\text { borrelia; human immunodeficiency virus (HIV); hepatitis C; Epstein-Barr (EB) virus; mumps, mea- } \\
\text { sles, and rubella viruses; brucellosis; tick-borne diseases; and malaria. }\end{array}$ \\
\hline & \multirow[t]{2}{*}{$\begin{array}{l}\text { Disseminated intravascular } \\
\text { coagulation (DIC) }\end{array}$} & $\begin{array}{l}\text { Acute DIC, such as shock, infection, and leukemia; chronic DIC, such as malignant tumors and } \\
\text { aneurysm }\end{array}$ \\
\hline & & Hemolysis, elevated liver enzymes, and low platelets syndrome (HELLP) \\
\hline & \multirow[t]{3}{*}{ Pregnancy-related diseases } & Acute fatty liver of pregnancy (AFLP) \\
\hline & & Amniotic fluid embolism \\
\hline & & Eclampsia \\
\hline & Thrombotic disease & Severe pulmonary embolism \\
\hline & \multirow{3}{*}{$\begin{array}{l}\text { Extracorporeal life support } \\
(\text { ECLS) }\end{array}$} & Extracorporeal membrane oxygenation (ECMO) \\
\hline & & Renal replacement therapy (RRT) \\
\hline & & Artificial liver support system (ALSS) \\
\hline & \multirow[t]{2}{*}{ Auxiliary circulation device } & Intra-aortic balloon counterpulsation (IABP) \\
\hline & & Ventricularassist device (VAD) \\
\hline & \multirow[t]{2}{*}{ TMA } & Thrombocytopenic purpura (TTP) \\
\hline & & Hemolytic uremic syndrome (HUS) \\
\hline & \multirow[t]{2}{*}{ Heat stroke } & Exertional heat stroke (EHS) \\
\hline & & Von Willebrand disease (VWD) \\
\hline & \multirow[t]{2}{*}{ Hematological diseases } & Hemophagocytic lymphohistiocytosis (HLH) \\
\hline & & $\mathrm{PNH}$ \\
\hline & Autoimmune disease & APS, autoimmune hemolyticanemia (AlHA), Evan's syndrome (AlHA + ITP) \\
\hline & Hyperfibrinolytic state & Cirrhosis, metastatic prostate/ovarian tumors \\
\hline \multirow{7}{*}{$\begin{array}{l}\text { Increased platelet } \\
\text { destruction }\end{array}$} & \multirow[t]{2}{*}{ Severe infection } & Dengue \\
\hline & & Classic drug-dependent antiplatelet antibodies, such as quinine \\
\hline & \multirow[t]{4}{*}{$\begin{array}{l}\text { Drug-induced immune } \\
\text { thrombocytopenia (DITP) }\end{array}$} & Hapten-induced antibodies, such as penicillin \\
\hline & & Drug-specific antibodies, such as tirofiban, etibeptide, and abciximab \\
\hline & & Drug-induced autoantibodies, such as levodopa and sulfa \\
\hline & & Formation of immune complex, such as HIT \\
\hline & Autoimmune disease & Systemic lupus erythenlatosus (SLE), rheumatoid arthritis (RA) \\
\hline \multirow{4}{*}{$\begin{array}{l}\text { Abnormal platelet } \\
\text { distribution }\end{array}$} & \multirow[t]{2}{*}{ Hematological diseases } & Primary immune thrombocytopenia (ITP) \\
\hline & & Posttransfusion purpura (PTP) \\
\hline & Hypersplenism & \\
\hline & Low temperature & \\
\hline
\end{tabular}


Table 1 Common causes of thrombocytopenia in critical care patients (Continued)

\begin{tabular}{ll}
\hline Type & \multicolumn{1}{c}{ Common causes } \\
\hline Hemodilution & $\begin{array}{l}\text { Massive rehydration or plasma } \\
\text { transfusion }\end{array}$
\end{tabular}

an average of $30 \times 10^{9} /(\mathrm{L} \cdot \mathrm{d})$ in survivors and $\leq 6 \times 10^{9} /$ $(\mathrm{L} \cdot \mathrm{d})$ in nonsurvivors [24].

\section{Diagnosis and differential diagnosis \\ Recommendation 6: It is important to understand the clinical background of thrombocytopenia in critical care patients to identify the cause}

The collection of a complete medical history helps to determine the cause of thrombocytopenia. Clinicians should ask patients detailed questions about symptoms of bleeding or thromboembolism; infection-related symptoms (viruses, bacteria, fungi, parasites, borrelia, rickettsia); any nutritional deficiencies in the diet; liver diseases; hypersplenism; history of autoimmune diseases, such as RA and SLE; history of bariatric surgery and blood transfusion; use of medications that may cause thrombocytopenia; family history of thrombocytopenia; and the results of previous platelet tests to determine the baseline platelet count [25].

A comprehensive physical examination is required to identify signs of bleeding or embolism on the skin and any other body part. Thrombocytopenia-related bleeding mainly manifests as skin petechiae and bruising, bleeding gums, nose bleeds, menorrhagia, joint or muscle hematoma, and in severe cases, hematuria, gastrointestinal bleeding, retinal hemorrhage, and even cerebral hemorrhage. In cases of venous thrombosis, lower limb deep venous thrombosis can cause lower limb swelling; pulmonary embolism can manifest as difficulty breathing and shock; renal venous thrombosis may cause renal failure; hepatic venous thrombosis may cause BuddChiari syndrome; and retinal venous thrombosis may cause blindness. Arterial thrombosis may cause cerebral infarction, myocardial infarction, renal failure, and gangrene [26]. In addition, clinicians should examine any yellowing of the skin and mucous membranes; swelling of the liver, spleen, or lymph nodes; and central nervous system disorders, such as confusion, convulsions, and speech disorders. For pregnant women, placental vascular thrombosis is often associated with habitual abortion, premature birth, stillbirth, preeclampsia, and HELLP [27].

\section{Recommendation 7: Comprehensive laboratory tests aid in the diagnosis of complicated thrombocytopenia}

There are many causes of thrombocytopenia, and sometimes, the cause may be misdiagnosed at the initial visit. Therefore, the following screening tests are recommended for patients with thrombocytopenia of an unknown cause (Table 2) [13, 14]. If routine screenings cannot determine the cause, additional tests may be performed based on the patient's medical history and clinical manifestations. For example, patients who have undergone platelet transfusion in the past 3 weeks can be tested for platelet-related antibodies to exclude PTP. Patients with recurrent arteriovenous embolism can be tested for anticardiolipin-antibodies (aCL), lupus anticoagulant (LAC), and $\beta_{2}$ glycoprotein-I ( $\beta_{2}$ GPI) antibodies [28]. Patients with thrombocytopenia, microangiopathic hemolysis, neurological symptoms, fever, and renal impairment may be tested for von Willebr and factor (vWF)- cleaving protease(ADAMTS13) activity and ADAMTS13 inhibitors [29]. Patients with clinically suspected hemophilia but normal factor VIII and IX activities may be tested for vWF antigen and activity to rule out VWD [30]. Patients with heparin exposure in the past 3 months and 4 Ts score $\geq 3$ may be tested for HIT antibodies [31]. The 4Ts score is

Table 2 Routine screening for thrombocytopenia

\begin{tabular}{|c|c|}
\hline Item & Diagnosis \\
\hline Blood test; C-reactive protein (CRP); procalcitonin (PCT) & Severe infection; hematological disease \\
\hline $\begin{array}{l}\text { Prothrombin time (PT), activated partial thromboplastin time (APTT), thrombin time (TT), fibrinogen } \\
\text { (Fib), D-dimer (DD), fibrindegradation products (FDP) }\end{array}$ & DIC; the cause should be determined \\
\hline Alanine aminotransferase (ALT), aspartate aminotransferase(AST), creatinine (Cr), total bilirubin (TBil) & $\begin{array}{l}\text { Thrombocytopenia due to liver and renal } \\
\text { impairment }\end{array}$ \\
\hline Lactic acid dehydrogenase (LDH) & $\begin{array}{l}\text { Hemolytic anemia; paroxysmal nocturnal } \\
\text { hemoglobinuria }\end{array}$ \\
\hline Vitamin B12, folic acid & Malnutrition-associated thrombocytopenia \\
\hline EBvirus, cytomegalovirus (CMV), hepatitis B virus (HBV), hepatitis C virus (HCV), HIV & Viral infection \\
\hline Antinuclear antibodies (ANA), rheumatoid factor (RF) & $\begin{array}{l}\text { Autoimmune diseases such as SLE, Sjogren's } \\
\text { syndrome, and RA }\end{array}$ \\
\hline
\end{tabular}


mainly used during initial HIT diagnosis and is the sum of four subscores, including the number of thrombocytopenia features, the duration of thrombocytopenia, the type of thrombosis, and other causes of thrombocytopenia. It is used to determine the likelihood of HIT: $\leq 3$, low; 4 to 5 , possible; 6 to 8 , probable.

\section{Recommendation 8: Routine bone marrow aspiration is not recommended for critical care patients with thrombocytopenia}

For ICU patients, thrombocytopenia is usually caused by sepsis, DIC, malnutrition, and drugs. Therefore, routine bone marrow aspiration is not recommended. However, bone marrow aspiration may be performed in cases of unknown cause and the presence of abnormalities of other blood cells [32]. Thiolliere et al [14]analyzed the results of bone marrow aspiration in 255 ICU patients and found that for patients with absolute thrombocytopenia, bone marrow aspiration showed (from more to less common) sepsis-related bone marrow features characterized by megakaryocyte depletion,normal bone marrow, folic acidand vitamin B12 deficiency-related changes, megaloblastosis, and hematological tumors. HLH should be considered in cases of thrombocytopenia with fever (temperature > $38.5^{\circ} \mathrm{C}$ for $>7 \mathrm{~d}$ ), splenomegaly, hemoglobin $<90 \mathrm{~g} / \mathrm{L}$ or neutrophil count $<1.0 \times 10^{9} / \mathrm{L}$, hypertriglyceridemia, hypofibrinogenemia, elevated serum ferritin, decreased natural killer (NK) cell activity, and elevated soluble CD25; and bone marrow aspiration should be performed to identify hemophagocytes to confirm the diagnosis [33].

\section{Recommendation 9: Peripheral blood smears can help diagnose thrombocytopenia in critical care patients}

Peripheral blood smears help to analyze the amount, size, and morphology of platelets; determine excessive platelet destruction or consumption [34]; identify pseudothrombocytopenia [8,9]; and differentiate acute febrile diseases such as sepsis, dengue, and Leptospira infection through granulocytic changes [35]. On peripheral blood smear, aberrant morphology of red blood cells or red blood cell fragments is a characteristic feature of TMA [36]. Moreover, red blood cells that are swollen or varied in size indicates folic acid or vitamin B12 deficiency. Deformed spherical, target-shaped, crescent, or angular red blood cells indicate hemolytic diseases such as DIC and AIHA. Large platelets $(>4 \mu \mathrm{m})$ are seen in Bernard-Soulier syndrome, Glanzmann thrombasthenia, myeloid leukemia, and ITP. Small platelets $(<1.5 \mu \mathrm{m})$ are seen inAA. Peripheral blood smear should be performed at the same time as bone marrow aspiration [37].
Recommendation 10: For thrombocytopenia accompanied by thromboembolic symptoms, differential diagnosis is required for conditions such as DIC, TMA, HELLP syndrome, APS, HIT, and PNH

Thrombocytopenia usually manifests as bleeding. In the case of thromboembolism or hemolysis, differential diagnosis is required for conditions such as DIC, TMA, HELLP, APS, HIT, and PNH [38]. In the case of DIC, many causes can lead to local microvascular injury, triggering extensive activation of the coagulation system and organ dysfunction. Sepsis-induced DIC is the most common type of DIC, and its incidence is 150 times that of TMA [39]. The main laboratory features of sepsisinduced DIC include thrombocytopenia, increased consumption of coagulation factors, and elevated fibrin markers.

TMA is usually secondary to specific conditions, such as malignant tumors, infection, collagenous disease, and pregnancy. TMA includes TTP, atypical HUS, and Shiga toxin-associated HUS. Despite having different mechanisms, these conditions share the common feature of microangiopathic hemolytic anemia, especially hemolytic anemia, thrombocytopenia, and organ failure [40].

Both DIC and TTP can cause microvascular thrombosis, but DIC mainly causes postcapillary small venous thrombosis due to activation of the coagulation system, whereas TTP mainly causes postcapillary small artery thrombosis due to platelet and vWF microaggregation [41]. Acquired TTP is caused by ADAMTS-13 autoimmune responses; as a result, ADAMTS-13 activity is typically $<10 \%$ in TTP and $>30 \%$ in DIC and other types of TMA, which is helpful for differential diagnosis [42].

Atypical HUS is characterized by vascular endothelial injury due to the excessive activation of complements, as well as platelet activation and hemolytic response [43]. Hemolysis can lead to the excessive release of red blood cell injury-related molecules such as free heme, which then induces the production of neutrophil extracellular traps (NETs), activates inflammatory-coagulant interactions, and leads to extensive thrombosis [44, 45]. Shiga toxin-associated HUS is more common than atypical HUS. Shiga toxin-associated HUS is caused by Shiga toxin-producing Escherichia coli, especially O157: H7 or O104: H4, which causes gastrointestinal infection, produces toxins that cause endothelial cell damage, induces complement deposition in endothelial cells, and interferes with complement activity [46]. Upon diagnosis, the preferred treatment for Shiga toxin-associated HUS is supportive care rather than antibiotics.

HELLP, a serious complication of pregnancy-associated preeclampsia, is characterized by impaired ADAMTS-13 activity, excessive release of vWF multimers, the production of activated $\mathrm{vWF}$, and subsequent microvascular platelet thrombosis [47]. Thrombocytopenia, 
microangiopathic anemia, and liver damage are the main clinical manifestations of HELLP. Timely delivery is the standard of care for HELLP. Acquired TTP should be considered if symptoms continue to worsen after delivery [48].

HIT is a condition induced by platelet-activating antibodies during treatment with heparin. It mainly manifests as thrombocytopenia, as well as venous and arterial thrombosis, and even death [49]. Literature review shows that the incidence of HIT is approximately 0.1 to $5.0 \%$, and the incidence is higher with unfractionated heparin use than with low-molecularweight heparin use [50]. HIT is mainly caused by platelet factor 4 (PF4)-heparin complex, which stimulates immune cells to produce PF4-heparin complex antibodies (i.e., HIT antibodies), which in turn leads to persistent platelet activation, activation of the coagulation pathway, platelet thrombosis, and fibrin thrombus [51]. HIT is diagnosed if the 4Ts score is $\geq 4$ in the presence of positive IgG-specific HIT antibodies [52]. HIT may be misdiagnosed in the presence of sepsis because both conditions may manifest as leukocytosis and ischemic limb necrosis. However, HIT often causes lower limb venous thrombosis, whereas DIC is more likely to cause symmetrical peripheral gangrenes [53].

APS is an autoimmune disease characterized by recurrent arteriovenous thrombosis, habitual abortion, cytopenia, and persistently positive (medium to high titers) antiphospholipid antibodies. It is most common in young women. Habitual abortion and intrauterine stillbirth are the main clinical manifestations in female APS patients [54]. Thrombosis can occur in any artery or vein, regardless of its size. A small number of patients may have multiple incidents of thrombosis within a week and subsequently develop acatastrophic vascular occlusion called catastrophic antiphospholipid syndrome (CAPS). APS is confirmed with routine tests that show thrombocytopenia, neutropenia, hemolytic anemia, and positive serum antiphospholipid antibodies (aCL, LAC, $\beta_{2}$ GPI antibodies) [55].

$\mathrm{PNH}$ is an acquired hemolytic disease resulting from defects in red blood cell membrane due to hematopoietic stem cell mutations. The main clinical manifestations are intravascular hemolytic anemia, cytopenia due to bone marrow failure, thrombosis, and smooth muscle dysfunction. Thrombosis often occurs in the hepatic vein, followed by mesenteric vein, cerebral vein, and lower lime deep vein, and arterial thrombosis is rare [56]. Typical cases show characteristic paroxysmal nocturnal hemoglobinuria. Flow cytometry is the gold standard for the diagnosis of $\mathrm{PNH}$.
Recommendation 11: Platelet function must be evaluated in case of thrombocytopenia

Platelet count directly affects platelet function. However, platelet function and platelet count are not necessarily in sync [57] in critical care patients due to different causes and stages and concomitant antiplatelet therapy in some patients $[58,59]$. Certain herbals or foods may inhibit platelet function, such as ginkgo, garlic, ginger, angelica, feverfew, ginseng, hawthorn, turmeric, and rographis, and dogwood [60]. Moreover, the early stage of sepsis is characterized by significantly enhanced platelet adhesion and aggregation. Even in the case of thrombocytopenia, platelet may still be hyperfunctional in sepsis patients [60], followed by decreased platelet aggregation along with excessive platelet consumption [61-63]. Trauma patients, especially those with brain injury, may experience decreased platelet aggregation even if platelet count is still in the normal range [64-66]. Trauma patients with prolonged use of oral antiplatelet drugs are particularly prone to adverse prognosis due to platelet dysfunction $[67,68]$. For acute myeloid leukemia (AML) patients with thrombocytopenia, platelet aggregation and activation tests are superior to platelet count in predicting the risk of bleeding [69]. Therefore, platelet function should be evaluated in case of thrombocytopenia.

Conventional platelet function tests analyze platelet adhesion, aggregation, and release during hemostasis [70, 71].Viscoelasticity-based tests(thromboelastography, coagulation and platelet function analyzer) can all comprehensively reflect the overall function of coagulation factors, fibrinogen, and platelets; and are used to guide platelet replacement therapy and antiplatelet therapy (Table 3) [72, 73]. Viscoelasticity-based tests such as thromboelastography and coagulation and platelet function analyzer indicate the contribution of platelets during coagulation. The results cannot be explained in the same manner as those of conventional platelet function tests because of different principles [74, 75]. For platelet function, the coagulation and platelet function analyzer is less affected by fibrinogen interference and is thus more accurate than thromboelastography [76, 77]. Light transmission aggregometry (LTA) and platelet function analyzer 100 (PFA-100) are susceptible to the effect of thrombocytopenia $\left(<100 \times 10^{9} / \mathrm{L}\right)$ and are thus not recommended for routine platelet function monitoring in patients with thrombocytopenia [78].

\section{Treatment}

Recommendation 12: Eliminating or controlling the causes of thrombocytopenia as soon as possible is a prerequisite for treatment

There are many causes of thrombocytopenia. To treat thrombocytopenia, clinicians must first eliminate or 
Table 3 Platelet function tests for patients with thrombocytopenia

\begin{tabular}{|c|c|c|c|}
\hline Experiment name & Experimental principle & Clinical significance & Limitations \\
\hline Thrombelastography & $\begin{array}{l}\text { Based on blood viscoelasticity, the device } \\
\text { activates coagulation through needle rotation, } \\
\text { thus simulating coagulation in vitro }\end{array}$ & $\begin{array}{l}\text { 1. It comprehensively reflect the function of } \\
\text { coagulation factors, platelets, and fibrinolysis } \\
\text { system } \\
\text { 2. Detect residual heparin and guide heparin } \\
\text { dosage } \\
\text { 3. The graph can be used to evaluate the efficacy } \\
\text { of thromboxane A2 (TXA2 in) inhibitors and } \\
\text { P2Y12 receptor inhibitors. }\end{array}$ & Long test time \\
\hline $\begin{array}{l}\text { Coagulation and } \\
\text { platelet function } \\
\text { analyzer }\end{array}$ & $\begin{array}{l}\text { Based on blood viscoelasticity, the device } \\
\text { observes vertical needle vibration to simulate } \\
\text { coagulation in vitro }\end{array}$ & $\begin{array}{l}\text { It comprehensively reflect the function of } \\
\text { coagulation factors and platelets and is } \\
\text { particularly accurate for evaluating platelet } \\
\text { function }\end{array}$ & \\
\hline $\begin{array}{l}\text { Whole-blood } \\
\text { platelet aggregation } \\
\text { rate }\end{array}$ & $\begin{array}{l}\text { Changes in platelet aggregation electrode } \\
\text { impedance caused by different stimuli }\end{array}$ & $\begin{array}{l}\text { 1. Posttrauma or postoperative platelet function } \\
\text { evaluation, and platelet count measurement } \\
\text { 2. Evaluation of the efficacy of antiplatelet drugs } \\
\text { (TXA2 inhibitors, P2Y12 receptor inhibitors) }\end{array}$ & $\begin{array}{l}\text { 1. The result may be } \\
\text { affected when platelet } \\
\text { count }<27 \times 10^{9} / \mathrm{L} \\
\text { 2. Test must be performed } \\
\text { within } 10 \text { min of sample } \\
\text { collection }\end{array}$ \\
\hline $\begin{array}{l}\text { VerifyNow platelet } \\
\text { function analysis }\end{array}$ & $\begin{array}{l}\text { Cassette detection based on changes in light } \\
\text { signals during platelet aggregation }\end{array}$ & $\begin{array}{l}\text { 1. Posttrauma or postoperative platelet function } \\
\text { evaluation to guide platelet transfusion } \\
\text { 2. Evaluation of the efficacy of antiplatelet drugs } \\
\text { (TXA2 inhibitors, P2Y12 receptor inhibitors, } \\
\text { glycoproteins IIb/IIla receptor inhibitors) }\end{array}$ & $\begin{array}{l}\text { 1. Not recommended for } \\
\text { hereditary platelet } \\
\text { dysfunction } \\
\text { 2. No established data on } \\
\text { the effect of } \\
\text { thrombocytopenia on the } \\
\text { result }\end{array}$ \\
\hline Flow cytometry & $\begin{array}{l}\text { Detection of fluorescent-labeled antibody and } \\
\text { cell size via light scattering }\end{array}$ & $\begin{array}{l}\text { 1. To diagnose defects in platelet surface } \\
\text { glycoproteins or platelet secretion } \\
\text { 2. To detect platelet-associated antibodies }\end{array}$ & Expensive \\
\hline
\end{tabular}

control the factors inducing thrombocytopenia as soon as possible. Discontinuation of drugs that cause thrombocytopenia is a first-line treatment for DITP [79]. Effective infection management is the prerequisite for treating sepsis-associated thrombocytopenia [80]. To treat thrombocytopenia caused by active bleeding, it is first necessary to effectively stop the bleeding [81]. For thrombocytopenia caused by immune diseases, the excessive immune response must be effectively controlled [82]. For ECLS-associated thrombocytopenia, the treatment plan should be adjusted in a timely manner to prevent excessive platelet consumption [83].

\section{Medical treatment \\ Recommendation 13: Vitamin B12 and folic acid can treat thrombocytopenia caused by vitamin B12 and folic acid deficiency}

Vitamin B12 and folic acid are important coenzymes for the synthesis of deoxyribonucleic acid (DNA). Critical care patients require more vitamin B12 and folic acid, which may lead to relative vitamin B12 and folic acid deficiency and subsequently tothrombocytopenia, megaloblastic anemia, and hyperhomocysteinemia [84]. Studies have shown that vitamin B12 or folic acid deficiency is associated with the severity of patient condition [85]. Folic acid deficiency may also occur during RRT [86]. Thiolliere et al [14] showed that folic acid and vitamin
B12 deficiency-related changes are common in bone marrow aspiration samples from ICU patients. Vitamin B12 deficiency may be accompanied by neurological symptoms. Folic acid deficiency may be accompanied by malignant anemia and mental disorders. Blood tests may indicate pancytopenia, and bone marrow aspiration may show myelodysplasia. Upon diagnosis, vitamin B12 and folic acid supplements can relieve symptoms.

\section{Recommendation 14: Thrombopoietic drugs can be used to treat bone marrow suppressive thrombocytopenia}

Thrombopoietin (TPO), a thrombopoietin receptor agonist, promotes megakaryocyte division into platelets and platelet release. It is mainly used to treat postchemotherapy thrombocytopenia, ITP, AA, and hepatitisassociated thrombocytopenia [87-91]. Some studies showed that for sepsis-associated thrombocytopenia, TPO treatment improved platelet count and reduced platelet transfusion [92]; however, other studies showed that blocking thrombopoietin reduced organ damage associated with sepsis [93]. Therefore, the role of TPO is still controversial in terms of improving the prognosis of sepsis.

Interleukin-11 (IL-11) is a cytokine produced by stromal cells and mesenchymal cells in the hematopoietic microenvironment. IL-11 binds to the specific receptor IL-11R $\alpha$ on the cell surface to stimulate proliferation of 
hematopoietic stem cells and megakaryocytic progenitor cells, induce differentiation and maturation of megakaryocytes, and promote platelet production [94, 95]. IL-11 has been approved for chemotherapy-related thrombocytopenia, leukemia, AA, and ITP [8, 96-98].

\section{Recommendation 15: Anticoagulation therapy is required when thrombocytopenia is combined with a prethrombotic state or a thrombus is already formed}

Prethrombotic state is a pathological state with high risk for thrombosis. The mechanisms include endothelial cell injury, elevated platelets and coagulation factors or their activity, decreased anticoagulants and fibrinolytic components or their activity, and slow blood flow. If thrombocytopenia is combined with prethrombotic state, anticoagulation therapy is required in order to prevent thrombosis. Immune dysfunction or severe infection often requires anticoagulation therapy as the condition may lead to multiple thrombosis and platelet depletion. Common anticoagulants include unfractionated heparin, low-molecular-weight heparin, argatroban, and bivalirudin. The choice of drugs depends on the mechanism and characteristics of the condition [99]. Anticoagulationtherapy is contraindicated for active bleeding.

Anticoagulation therapy may beinitiated in APS patients with recurrent lower limb deep venous thrombosis, pulmonary embolism, persistently high antibody titers, or hypercoagulable state. For recurrent venous thrombosis, unfractionated heparin or low-molecularweight heparin (anti-Fxa, 0.3 to $0.7 \mathrm{U} / \mathrm{mL}$ ) may be used in combination with warfarin for 3 to 5 days, followed by warfarin alone for 12 months to maintain prothrombin time/international normalized ratio (PT-INR) at 2.5. For recurrent arterial thrombosis, warfarin may be used for 12 months to maintain PT-INR at 3.0 [100, 101].

For patients with highly suspected or confirmed HIT, heparin should be discontinued and replaced with nonheparin anticoagulants, such as argatroban or bivalirudin [31, 51]. Argatroban is metabolized in the liver and can lead to significantly prolonged TT. The recommended starting dose of argatroban is 0.2 to $0.5 \mu \mathrm{g} / \mathrm{kg} / \mathrm{min}$ iv; the dose may be adjusted for patients with liver failure. The active anticoagulation ingredient of bivalirudin is hirudin-derived fragment, which is reversible and fastacting and has a half-life of 25 to $30 \mathrm{~min}$. The initial dose is $0.05 \mathrm{mg} / \mathrm{kg} / \mathrm{h}$. The anticoagulation treatment target is APTT elongation of 1.5 to 3.0 times the baseline level $(\leq 100 \mathrm{~s})$. After dose adjustment, APTT is monitored every $4 \mathrm{~h}$ and then every day once the target has been met for at least 2consecutive times [102]. After the condition is stabilized, the patient may be switched to oral anticoagulants once the platelet count is $\geq 100 \times 109$ $\mathrm{L}$ or has returned to baseline level. If warfarin is used, it must be used with intravenous anticoagulants for 5 days and then alone once the INR target has been met. If novel oral anticoagulants (NOACs) such as rivaroxaban are used, they may be started in $2 \mathrm{~h}$ after the discontinuation of intravenous anticoagulants [103].

Patients with sepsis-associated DIC are prone to extensive microthrombosis load and multiorgan dysfunction due to the upregulation of the procoagulant mechanism, an impaired anticoagulant mechanism, and the inhibition of fibrinolysis. Anticoagulation therapy protects the vascular endothelium, reduces platelet and coagulant consumption, reduces the thrombus load, and protects organ function [104]. Studies have shown that heparin anticoagulants reduce the mortality of sepsis $[105,106]$. For sepsis patients, anticoagulation therapy should be administered in cases of persistent decline in platelet count, persistent elongation of coagulation time, organ dysfunction due to microthrombosis, and when required to manage thrombotic events duringthe hypercoagulable stage of DIC [107]. If the patient is in a hypocoagulable state and at risk for bleeding, anticoagulation therapy may be providedwhile replenishing the patient's coagulation substrates [108]. Randomized controlled trials (RCTs) have shown that recombinant activated protein $\mathrm{C}$, tissue factor pathway inhibitor (TFPI), and thrombomodulin (TM) have no effect in improving the prognosis of sepsis [109-111].

For patients with heat stroke, significantly elevated core temperature leads to extensive endothelial cell injury, full activation of the coagulation system, rapid platelet consumption, and even DIC. Heatstrokeinduced DIC also requires anticoagulation therapy while replenishing coagulation substrates. Unfractionated heparin is the preferred treatment [112].

\section{Recommendation 16: Antiplatelet therapy should be administered with caution after a comprehensive evaluation of the risk of bleeding when thrombocytopenia is combined with a prethrombotic state or a thrombus is already formed}

For patients with thrombocytopenia, compensatory platelet hyperaggregation may increase the risk of platelet thrombosis [113]. Studies have shown that after coronary bypass grafting, the incidence of thrombocytopenia is $71.5 \%$, and the risk of delayed ischemic stroke ( $\geq 2$ days after operation) increases by $12 \%$ for every $30 \times 10^{9} / \mathrm{L}$ decline in platelet count [114]. However, no guidelines have been established for antiplatelet therapy in patients with thrombocytopenia. Myles et al. [115] showed that for coronary bypass grafting, preoperative discontinuation of aspirin has no effect on postoperative bleeding or thrombosis. On the other hand, Saw et al. [116] showed that after coronary bypass grafting, ticagrel or combined with aspirin reduces embolic complications of the graft. Therefore, accurate 
evaluation of platelet function and coagulation state in patients with thrombocytopenia is a prerequisite for antiplatelet therapy planning. Antiplatelet therapy may be started in cases of thrombocytopenia combined with a high risk of thrombosis [117]. After the start of antiplatelet therapy, the treatment response should be monitored to evaluate efficacy and the risk of bleeding.

For patients with acute coronary syndrome (ACS), the incidence of thrombocytopenia is as high as $13 \%$, especially in elderly patients with diabetes or heart and kidney dysfunction [118]. For ACS patients, antiplatelet therapy in the presence of thrombocytopenia increases the risk of bleeding; therefore, care must be taken during antiplatelet therapy to avoid concomitant nonsteroidal anti-inflammatory drugs and glycoprotein IIb/IIIa receptor antagonists. Moreover, aspirin should be started at a low dose, triple-antiplatelet therapy should be avoided in patients with prolonged anticoagulation therapy, concomitant proton pump inhibitors may be provided, and drug-coated stents should be used whenever possible [119]. Patients who must undergo percutaneous coronary interventions may be given aspirin combined with clopidogrel as antiplatelet therapy for 1 month, followed by clopidogrel alone when the platelet count reaches 50 to $100 \times 10^{9} / \mathrm{L}$ with no active bleeding. Patients who have not undergone percutaneous coronary interventions may be given clopidogrel alone as antiplatelet therapy. All antiplatelet drugs should be discontinued and percutaneous coronary intervention avoided if the platelet count is $<50 \times 10^{9} / \mathrm{L}$ or if active bleeding occurs.

\section{Recommendation 17: Antifibrinolytic therapy is required when thrombocytopenia is accompanied by hyperfibrinolysis}

Thrombocytopenia caused by trauma-induced bleeding, severe liver disease, acute promyelocytic leukemia, or snake bite is often accompanied by hyperfibrinolysis [120]. Bleeding due to severe trauma can lead to thrombocytopenia; meanwhile, excessive release of protein $\mathrm{C}$ inhibits the activity of plasminogen activator inhibitior-1 (PAI-1), resulting in relatively enhanced tissue-type plasminogen activator ( $t$ PA) activity and hyperfibrinolysis, which requires antifibrinolytic therapy. In the case of a propensity towards major bleeding after severe trauma, tranexamic acid ( $1 \mathrm{~g}$ iv over $10 \mathrm{~min})$ should be administered as soon as possible, followed by $1 \mathrm{~g}$ iv over $8 \mathrm{~h}$ [121, 122]. For VWD patients with thrombocytopenia, antifibrinolytic therapy may be administered as an adjuvant treatment in cases of oral mucosal bleeding or excessive menstrual bleeding [123, 124].

\section{Recommendation 18: Desmopressin improves platelet} function in patients receiving antiplatelet drugs

1-deamino-8-D-arginine vasopressin (DDAVP) promotes the release of vWF and factor VII from endothelial cells, promotes the expression of platelet membrane glycoproteins and enhances platelet adhesion and aggregation. It is the preferred treatment for VWD-related bleeding [125-127]. Clinical studies have shown that DDAVP improves postoperative platelet function and bleeding time in uremic patients [128], improves platelet aggregation in patients taking aspirin and/orclopidogrel [129-131], and reduces postoperative bleeding in cardiac patients taking aspirin [132, 133], with very low incidences of cardiovascular and cerebral vascular thrombosis complications [134]. DDAVP $(0.4 \mu / \mathrm{kg}$ iv over $30 \mathrm{~min})$ may be given in cases of cerebral hemorrhage in patients receiving antiplatelet drugs or in cases of injury in VWD patients $[135,136]$.

\section{Recommendation 19: Glucocorticoids reduce platelet destruction and can be used to treat immune thrombocytopenia}

Glucocorticoids inhibit the production of autoantibody IgG, stabilize platelets and the endothelial cell membrane, reduce the destruction of platelets and red blood cells, and stimulate bone marrow hematopoiesis. They are the first-line treatment for ITP and the main treatment for TTP and CAPS [137-139].

Glucocorticoid regimens vary according to the specific cause of thrombocytopenia. For ITP, the general recommendation is for oral glucocorticoids, such as prednisone $1 \mathrm{mg} / \mathrm{kg} /$ day, which can be tapered to 5 to $10 \mathrm{mg} /$ day for 3 to 6 months once the patient's condition has stabilized. During tapering, the minimum maintenance dose may be given in cases of thrombocytopenia. The prednisone dose should be quickly reduced and the drug should be withdrawn in the case of a lack of response after 4 weeks of treatment. Moreover, oral dexamethasone may be given at $40 \mathrm{mg} /$ day for 4 days and may be repeated in 2 weeks in the case of a lack of response $[89,140]$.

Studies have shown that for TTP, high-dose glucocorticoids (methylprednisolone $10 \mathrm{mg} / \mathrm{kg} /$ day) is more effective than low-dose glucocorticoids (methylprednisolone $1 \mathrm{mg} / \mathrm{kg} / \mathrm{day}$ ). Therefore, for TTP, methylprednisolone $1 \mathrm{~g}$ /day iv over $2 \mathrm{~h}$ for 3 days immediately after plasma exchange is recommended [141]. No empirical evidence is available for the tapering regimen, which is generally based on the platelet count and ADAMTS13 level. Except under special circumstances, the patient may be switched to prednisone $1 \mathrm{mg} / \mathrm{kg} /$ day, followed by tapering once the patient's condition has stabilized [142]. Dexamethasone $40 \mathrm{mg} /$ day for 4 days may be used to treat relapsed or refractory ITP or as an alternative to 
first-line treatment [143]. High-dose dexamethasone may increase the platelet count in a shorter time, but whether its overall response is superior to that of methylprednisolone is inconclusive [144]. Despite the lack of empirical evidence, high-dose glucocorticoids are recommended for the treatment of CAPS [145]. Septic shock patients often have thrombocytopenia and may receive hydrocortisone $200 \mathrm{mg} /$ day iv in the case of hemodynamic instability after sufficient rehydration and vasoactive treatment [146].

\section{Recommendation 20: Intravenous immunoglobulin (IVIg) and monoclonal antibody drugs are the main treatments for immune thrombocytopenia}

IVIg was used as a first-line treatment for ITP as long agoin 1981, with a response rate of 70 to $80 \%$ for ITP. $\gamma$-globulin competitively inhibits binding between antigen-presenting cells and $\mathrm{T}$ cells, blocks activated $\mathrm{Fc} \gamma$ receptors, upregulates the inhibitory receptor Fcy RIIB, inhibits the complement cascade, and neutralizes pathological autoantibodies and pathogenic cytokines, thus playing a role in regulating immune balance [147]. The dose of IVIg is usually $400 \mathrm{mg} /(\mathrm{kg} \cdot \mathrm{d})$ for 5 days or $1 \mathrm{~g} /(\mathrm{kg} \cdot \mathrm{d})$ for 1 to 2 days. IVIg is faster-acting than glucocorticoids for the treatment of ITP and usually takes effect in 24 to $48 \mathrm{~h}$; therefore, it is often used to treat ITP with major bleeding, ITP patients who require emergency invasive surgery (preoperative preparation), and refractory ITP [148].

IVIg combined with plasma exchange is considered a powerful treatment for refractory TTP and CAPS [149, 150]. Moreover, IVIg may be administered to treat DITP or PTP with severe thrombocytopenia (platelet count $<5 \times 10^{9} / \mathrm{L}$ ) or life-threatening bleeding [151]. High-dose IVIg may be effective for HIT that does not respond to conventional anticoagulation therapy [146, 152, 153]. Currently, IVIg is not recommended for the treatment of septic shock associated with thrombocytopenia [154].

Rituximab, a human-mouse chimeric monoclonal antiCD20 antibody, clears B lymphocytes from the blood, lymph nodes, and bone marrow. The standard dose is $375 \mathrm{mg} / \mathrm{m}^{2}$ once a week for 4 weeks. Moreover, rituximab $100 \mathrm{mg}$ once a week for 4 weeks is equally effective but takes longer to take effect [89]. Rituximab can be used as a first-line treatment for severe or recurrent TTP and as a second-line treatment for ITP. Caplacizumab is a potent and selective bivalent anti-vWF nanobody that has been approved in Europe for acquired TTP. It blocks the interaction between ultra large vWF multimers (ULvWF) and platelets and can be used as a first-line treatment for severe TTP [142].
Recommendation 21: Immune thrombocytopenia that does not respond to conventional treatment may be treated with immunosuppressive agents

For most cases of immune thrombocytopenia, immunosuppressive agents can be used as a second-line treatment for APS, AIHA, ITP, and TTP that does not respond to conventional treatment [28, 89, 142, 155]. Moreover, immunosuppressive agents can be used as a first-line treatment for immune diseases that manifest mainly as pancytopenia, such as HLH [156]. Common immunosuppressive agents include vincristine (VCR), cyclosporine A, cyclophosphamide, chloroquine, azathioprine, triptolide, and danazol. Because of their significant side effects, immunosuppressive agents are usually used in patients who do not respond to conventional treatment, and the treatment regimen must be individualized. Immunosuppressive agents can reduce the dose of glucocorticoids in combination therapy.

\section{Alternative treatment \\ Recommendation 22: Platelet transfusion can be performed when thrombocytopenia increases the risk of bleeding or if bleeding has occurred}

Three platelet products are commonly used in China. Platelets prepared from $200 \mathrm{ml}$ of whole blood are referred to as 1 unit of platelet concentrate. The concentration and purity of platelet concentrate are high, with $\geq 2.0 \times 10^{10}$ platelets per unit. Generally, multiple bags are required. Two or more bags of platelet concentrate are pooled into one bag to prepare pooled platelet concentrate, with $\geq 2.0 \times 10^{10}$ platelets per pooled unit. Platelets collected with anapheresis machine from the circulating blood sample of a single donor are called apheresis platelets or hemapheresis platelets. The purity of this product is high, with $\geq 2.5 \times 10^{11}$ platelets per unit, and it is superior to platelet concentrate for reducing the risk of alloimmune responses [157].

Platelet transfusion is used to prevent and treat bleeding in patients with thrombocytopenia or platelet dysfunction. It may be delivered as a preventive transfusion (in cases of thrombocytopenia or platelet dysfunction with no bleeding) or therapeutic transfusion (in cases of thrombocytopenia or platelet dysfunction with signs of bleeding) [158]. Preventive transfusion is contraindicated in patients with PTP, TTP, HUS, or HIT with no lifethreatening bleeding [32]. Before platelet transfusion, clinicians should evaluate the risk of bleeding, platelet count and platelet function, and any scheduled invasive treatment [159].

For nonbleeding patients in stable condition, platelet transfusion is recommended if the platelet count is $\leq 10 \times 10^{9} / \mathrm{L}$; for nonbleeding patients in unstable condition (such as those with fever or infection), platelet transfusion is recommended if the platelet count is < 
$20 \times 10^{9} /$ L. For patients undergoing invasive procedures and surgical preventive transfusion, platelet transfusion is recommended if the platelet count is $<20 \times 10^{9} / \mathrm{L}$ in patients with an indwelling central venous catheter. For patients undergoing ECLS, elective diagnostic lumbar puncture, or non-axonal surgery, platelet transfusion is recommended if the platelet count is $<50 \times 10^{9} / \mathrm{L}$. For patients with scheduled spinal anesthesia, platelet transfusion is recommended if the platelet count is $\leq 80 \times 10^{9} /$ L. For patients with scheduled neurosurgery or eye surgery, platelet transfusion is recommended if the platelet count is $\leq 100 \times 10^{9} / \mathrm{L}$. For patients with active bleeding, the platelet count should be maintained at $50 \times 10^{9} / \mathrm{L}$. For patients undergoing cardiothoracic surgery with coagulation abnormalities and major microvascular bleeding, platelet transfusion is recommended if the platelet count is $<100 \times 10^{9 /} \mathrm{L}$. [157]

The platelet transfusion amount should be individualized, taking into account the patient's weight, spleen function, and other depletion factors. The dose is generally 1 unit of apheresis platelets or an equivalent dose of platelet concentrate per dosing; $\geq 2$ units of apheresis platelets may be transfused in the case of severe lifethreatening bleeding. After transfusion, the dose should be adjusted based on its effectiveness; the goal is to transfuse the minimum dose required to maintain the platelet count target. One unit of platelets can theoretically increase the platelet count by $4 \times 10^{9}$ to $8 \times 10^{9} / \mathrm{L}$ in adults (70 kg body weight).

For patients receiving antiplatelet therapy, bleedinginduced thrombocytopenia significantly increases mortality, blood loss, and the surgery rate [160, 161]. For patients receiving antiplatelet therapy for platelet dysfunction, their prognosis is related to the antiplatelet drugs given. Studies have shown that for patients taking aspirin, severe trauma and even brain injury do not increase mortality but will require significantly more transfused blood [162]. For patients taking clopidogrel, severe trauma will significantly increase mortality [163, 164]. Therefore, for patients undergoing antiplatelet therapy, platelet transfusion is recommended in cases of persistent bleeding with platelet dysfunction or even thrombocytopenia [165]. For patients receiving antiplatelet therapy, platelet transfusion is recommended in cases of surgical treatment for cerebral hemorrhage [166]. However, platelet transfusion is not recommended for patients receiving antiplatelet therapy who have cerebral hemorrhage that does not require surgical treatment $[167,168]$. The use of platelet count as an indication for platelet transfusions has not been shown to improve the outcomes of critical care patients $[169,170]$. The use of platelet function parameters to guide platelet transfusion in critical care patients with thrombocytopenia may be beneficial for improving the outcomes of these patients [171-173].

\section{Recommendation 23: $A B O / R h D$-compatible platelets are preferred for blood transfusion}

$\mathrm{ABO}$ blood group selection for platelet transfusion: $\mathrm{ABO}$-compatible platelets are preferred forplatelet transfusion; $\mathrm{ABO}$-incompatible platelets (i.e., the second best choice) may be used in cases of life-threatening bleeding with no available ABO-compatible platelets [174]. Platelet transfusion with minor $\mathrm{ABO}$ incompatibility (the presence of antibodies in donor plasma against the red blood cell and platelet $\mathrm{ABH}$ antigens of the recipient) and platelet transfusion with major $\mathrm{ABO}$ incompatibility (the presence of antibodies in recipient plasma against red blood cell and platelet $\mathrm{ABH}$ antigens of the donor) pose the risk of hemolytic reaction. Generally, adult patients are able to dilute or neutralize incompatible antibodies in the transfused plasma, and most show a positive result in direct antiglobulin tests, with no signs of hemolytic reaction [175]. Foreign studies have shown that $\mathrm{ABO}$ incompatibility has no significant effect on the effectiveness of transfusion. Therefore, some researchers suggest that the effect of $\mathrm{ABO}$ incompatibility on the effectiveness of platelet transfusion is negligible in patients who do not require long-term platelet transfusion, especially surgical patients [176].

$\mathrm{RhD}$ blood group selection for platelet transfusion: D antigen is the most immunogenic antigen in the Rh system. The Rh blood group is either "Rh positive" or " $\mathrm{Rh}$ negative" based on the presence of $\mathrm{D}$ antigen in red blood cells. Despite a lack of D antigen in platelets, platelet products contain a certain amount of red blood cells $(<1 \mathrm{~mL}$ of red blood cells per therapeutic unit of apheresis platelets, and more in platelet concentrate), which can cause sensitization and thereby pose a risk to the safety of future blood transfusions in RhD-negative patients and a risk of neonatal hemolytic disease during future pregnancies in female patients. Therefore, RhDnegative patients should receive $\mathrm{RhD}$-negative platelets whenever possible, but RhD-incompatible platelets may be transfused in emergencies [174]. Anti-D antibodies are recommended in RhD-negative women with childbearing potential who have received $\mathrm{RhD}$-positive platelet transfusion [158].

\section{Recommendation 24: Effectiveness should be evaluated after platelet transfusion}

Platelet transfusion refractoriness (PTR) refers to alack of a significant platelet increase or even a decline 2 consecutive times after adequate platelet transfusion, with no improvement in clinical bleeding [177]. PTR may be caused by nonimmune or immune factors. Common nonimmune factors include traumatic coagulopathy, splenomegaly, DIC, and excessive platelet consumption due to inappropriate transfusion. The following precautions are recommended for platelet transfusion: mix the 
blood bag gently before transfusion and transfuse as fast as possible (per patient tolerance); unused platelets should not be stored in the refrigerator but can be kept at room temperature for a short time, preferably on a platelet shaker. Alloimmune PTR, the most common immune factor-induced disease, is defined as a platelet increase $<5 \times 10^{9} / \mathrm{L}$ in $10 \mathrm{~min}$ to $1 \mathrm{~h}, 2$ consecutive times, after the transfusion of $\mathrm{ABO}$-compatible platelets in patients with thrombocytopenia due to loss of bone marrow function who have no clear nonimmunological factors [178]. Alloimmune PTR is caused by the production of antiplatelet antibodies in response to repeated platelet transfusions and subsequent immune responses with newly transfused platelets, which causes the destruction of transfused platelets and PTR [179]. Antigen A, antigen B, human leukocyte antigen (HLA) antibodies, and human platelet antigen (HPA) are common causes of immune PTR. Therefore, PTR patients should receive ABO-, HLA-, or HPA-compatible platelets whenever possible [180, 181].

\section{Plasma exchange \\ Recommendation 25: Plasma exchange eliminates abnormal immune antibodies and reduces platelet destruction}

Plasma exchange is effective for platelet destruction due to abnormal immune antibodies and is recommended for TTP, CAPS, refractory ITP, atypical HUS, HELLP, and PSP. It is not recommended for Shiga toxinassociated classic HUS with no central nervous system symptoms or for Streptococcus pneumoniae-associated HUS [182, 183].

Plasma exchange can be used as conventional treatment or an intensive treatment. For TTP, the recommended conventional treatment is 40 to $60 \mathrm{~mL} / \mathrm{kg}$ per session, $\leq 2$ times per day, until the symptoms have improved, LDH is normal, and platelet count is normal or elevated [184]. If $\mathrm{LDH}$ remains elevated or platelet count is persistently low after 7 days of daily plasma exchange, refractory TTP is considered; this condition requires intensive plasma exchange (2 times per day) combined with glucocorticoids or immunosuppressive agents [142, 185, 186].

Plasma exchange may be performed in patients undergoing ECMO who have heparin-induced HIT or significant thrombosis and require the rapid elimination of excessive anti-PF4-heparin antibodies [187, 188]. Several studies have shown that plasma exchange is effective for HIT [189].

For patients with septic shock, the incidence of thrombocytopenia may be $50 \%$ or higher, with a significantly increased risk of mortality [190, 191]. Studies have shown that early plasma exchange in patients with septic shock, especially in patients who require high-dose vasoactive drugs to maintain hemodynamics, reduces the dose of vasoactive drugs, removes inflammatory cytokines, and reduces capillary leakage and platelet consumption [192-194].

\section{Surgical treatment \\ Recommendation 26: Splenectomy should be used with caution for thrombocytopenia}

Splenectomy eliminates the site responsible for the production of autoantibodies and the destruction of red blood cells and platelets. It can be used to treat immune antibody-mediated thrombocytopenia refractory to conventional treatment, such as refractory ITP, TTP, and AIHA [89, 142, 195]. Splenectomy is indicated in patients whose course of disease is $>6$ months and who do not respond to regular steroid treatment; patients who respond to steroid treatment but require high-dose maintenance therapy; and patients contraindicated for steroid therapy [89]. The main complications of surgical treatment are bleeding and secondary infection. Laparoscopic minimally invasive surgery is an effective method for reducing complications [196].

\section{Prevention \\ Recommendation 27: Influencing factors of thrombocytopenia need to be actively controlled during ECLS}

ECLS refers to the use of extracorporeal equipment to completely or partially replace organ function to provide life support in the case of life-threatening organ dysfunction. ECLS broadly includes ECMO, which supports cardiopulmonary function; RRT, which supports renal function; and ALSS, which supports liver function [197].

During ECLS, blood passes through the extracorporeal circulation line. The contact between blood and circuit material may activate the extrinsic coagulation pathway and initiate coagulation, resulting in the additional consumption of platelets and coagulation factors [198]. Anticoagulant drugs that prevent coagulation in the circuit may also affect the patient's coagulation state, increasing the risk of bleeding-induced thrombocytopenia or inducing HIT [199]. Guru et al. [200] showed that among critical care patients scheduled to receive continuous RRT (CRRT), 65\% have thrombocytopenia, and an additional $20 \%$ have thrombocytopenia during CRRT. Patients receiving CRRT and heparin anticoagulation have more significant platelet decline than patients receiving heparin anticoagulation alone, without CRRT. The 4Ts score indicates that most patients meet the criteria for a diagnosis of HIT; however, the rate of markedly positive antibodies is actually low [201]. Choi et al. [202] showed that the incidence of thrombocytopenia is up to $83 \%$ in patients receiving ECMO. VA-ECMO is more likely than VV-ECMO to cause thrombocytopenia. 
This is related to platelet consumption due to athrombus caused by membrane oxygenator-induced vWF aggregation [203]. The duration of ECMO is largely unrelated to thrombocytopenia [204]. During ECMO, the incidence of HIT is approximately $20 \%$. In most cases, PF4 antibody results are positive during ECMO.HIT should be considered in cases of frequent abnormalities in the ECMO circuit, progressive platelet decline, and high levels of PF4-specific IgG antibodies [205]. Therefore, during ECLS, clinicians should comprehensively evaluate coagulation function, choose an appropriate anticoagulation regimen, and make every effort to control influencing factors of thrombocytopenia. In cases of thrombocytopenia during ECLS, clinicians should actively identify the cause and discontinue anticoagulation therapy if needed $[83,206]$.

\section{Abbreviations}

AA: Aplastic anemia; ACS: Acute coronary syndrome; AFLP: Acute fatty liver of pregnancy; AlHA: Autoimmune hemolytic anemia; ALSS: Artificial liver support system; ALT: Alanine aminotransferase; AML: Acute myeloid leukemia; ANA: Antinuclear antibodies; APS: Antiphospholipid syndrome; APTT: Activated partial thromboplastin time; AST: Aspartate aminotransferase; CAPS: Catastrophic antiphospholipid syndrome; CMV: Cytomegalovirus; CRP: C-reactive protein; DD: D-dimer; DIC: Disseminated intravascular coagulation; DNA: Deoxyribonucleic acid; ECLS: Extracorporeal life support; ECMO: Extracorporeal membrane oxygenation;

EDTA: Ethylenediaminetetraacetic acid; EHS: Exertional heat stroke; FDP: Fibrin degradation products; HBV: Hepatitis B virus; HCV: Hepatitis C virus; HELLP: Hemolysis, elevated liver enzymes, and low platelets syndrome; HIT: Heparin-induced thrombocytopenia; HIV: Human immunodeficiency virus; HUS: Hemolytic uremic syndrome; HLA: Human leukocyte antigen; HLH: Hemophagocytic lymphohistiocytosis; HPA: Human platelet antigen; IABP: Intra-aortic balloon counter pulsation; ICU: Intensive care unit; IL: Interleukin; IVlg: Intravenous immunoglobulin; ITP: immune thrombocytopenia; LAC: Lupus anticoagulant; LDH: Lactic acid dehydrogenase; LTA: Light transmission aggregometry; MDS: Myelodysplastic syndrome; NETs: Neutrophil extracellular traps; NOAC: Novel oral anticoagulants; PAl: Plasminogen activator inhibitior; PCT: Procalcitonin; PF: Platelet factor; PNH: Paroxysmal nocturnal hemoglobinuria; PT: Prothrombin time; PTP: Posttransfusion purpura; PTR: Platelet transfusion refractoriness; RA: Rheumatoid arthritis; RCT: Randomized controlled trial; RF: Rheumatoid factor; RRT: Renal replacement therapy; SLE: Systemic lupus erythenlatosus; TFPI: Tissue factor pathway inhibitor; TM: Thrombomodulin; TMA: Thrombotic microangiopathy; t-PA: Tissue-type plasminogen activator; TPO: Thrombopoietin; TT: Thrombin time; TTP: Thrombocytopenic purpura; VAD: Ventricular assist device; WWD: Von Willebrand disease

\section{Acknowledgements}

Not applicable.

\section{Ethics approval and consent to participate}

Not applicable.

\section{Authors' contributions}

JCS, WQL, JW as the main person in charge of the consensus, presided over the expert seminar, suggested the consensus agenda and coordinated the expert groups. SYL, FZ, AQW, LHM were the main participants in the consensus discussion, formulating the consensus framework and proposing to update the main points. JCS was the first writing author of the manuscript. Other experts participate in literature review, data collection, consensus discussion, subitem discussion and suggestions, recommendations. All authors read and approved the final manuscript.

\section{Authors' information}

Consultants: Hong-Yuan Lin, Qing Song, Cheng-Bin Wang.
Members of the Editorial Board (in alphabetical order): Yun-Liang Cui, ChenFang Fan, Yan Gao, Hong-Jun Kang, Feng Li, Fu-Xiang Li, Wei-Qin Li, ShuYuan Liu, Zhao-Fen Lin, Lin-Hao Ma, Bo Ning, Zhi-Guo Pan, Jing-Chun Song, Zhen-Ju Song, Zhi-Hui Tong, Jun Wu, Gang Wang, Xiao-Zhong Wang, XueFeng Wang, Ai-Qing Wen, Xiao-Ran Xiong, Wei Xu, Li-Kun Yang, Rong-Li Yang, Wei Zhang, Xi-Jing Zhang, Fei-Hu Zhou, Xin Zhou, Feng Zhu, HongQuan Zhu.

Secretaries: Qing-Wei Lin, Lin-Cui Zhong, Qing-Bo Zeng, Xing-Ping Deng.

\section{Funding}

Not applicable.

\section{Availability of data and materials}

Not applicable.

\section{Consent for publication}

Not applicable.

\section{Competing interests}

No conflicts of interest to disclose.

\section{Author details}

${ }^{1}$ Department of Critical Care Medicine, the 908th Hospital of Joint Logistics Support Forces of Chinese PLA, Nanchang 360104, China. ${ }^{2}$ Emergency Department, the Sixth Medical Center, Chinese PLA General Hospital, Beijing 100048, China. ${ }^{3}$ Burns and Trauma ICU, Changhai Hospital, Naval Medical University, Shanghai 200003, China. ${ }^{4}$ Department of Blood Transfusion, Daping Hospital of Army Medical University, Chongqing 400042, China. ${ }^{5}$ Department of Emergency and Critical Care Medicine, Changzheng Hospital, Naval Medical University, Shanghai 200003, China. ${ }^{6}$ Surgery Intensive Care Unit, Jinling Hospital, Medical School of Nanjing University, Nanjing 210002, China. ${ }^{7}$ Department of Clinical Laboratory, Peking University Fourth School of Clinical Medicine, Beijing Jishuitan Hospital, Beijing 100035, China.

Received: 12 March 2020 Accepted: 20 March 2020

Published online: 03 April 2020

\section{References}

1. Hui P, Cook DJ, Lim W, Fraser GA, Arnold DM. The frequency and clinical significance of thrombocytopenia complicating critical illness: a systematic review. Chest. 2011;139(2):271-8.

2. Williamson DR, Lesur O, T'etrault JP, Nault V, Pilon D. Thrombocytopenia in the critically ill: prevalence, incidence, risk factors, and clinical outcomes. Can J Anaesth 2013;60(7):641-651.

3. Williamson DR, Albert M, Heels-Ansdell D, Arnold DM, Lauzier F, Zarychanski $\mathrm{R}$, et al. Thrombocytopenia in critically ill patients receiving thromboprophylaxis: frequency, risk factors, and outcomes. Chest. 2013; 144(4):1207-15

4. Lauzier F, Arnold DM, Rabbat C, Heels-Ansdell D, Zarychanski R, Dodek P, et al. Risk factors and impact of major bleeding in critically ill patients receiving heparin thromboprophylaxis. Intensive Care Med. 2013;39(12): 2135-43.

5. Strauss R, Wehler M, Mehler K, Kreutzer D, Koebnick C, Hahn EG. Thrombocytopenia in patients in the medical intensive care unit: bleeding prevalence, transfusion requirements, and outcome. Crit Care Med. 2002; 30(8):1765-71.

6. Ministry of health of the people's Republic of China. Reference interval for blood cell analysis: WS / T 405-2012 [S], 2012.

7. Thiele T, Selleng K, Selleng S, Greinacher A, Bakchoul T. Thrombocytopenia in the intensive care unit diagnostic approach and management. Semin Hematol. 2013;50(3):239-50.

8. Ma J, Qin SK, Hou M, Shao ZH. Expert consensus on the clinical application of recombinant human interleukin-11 in the treatment of thrombocytopenia in China (2018). J Clin Oncol. 2018;23(3):260-6.

9. Lippi G, Plebani M. EDTA-dependent pseudothrombocytopenia: further insights and recommendations for prevention of a clinically threatening artifact. Clin Chem Lab Med. 2012;50(8):1281-5.

10. Dumont P, Goussot V, David A, Lizard S, Riedinger JM. Identification and validation of a factor of commutability between platelet counts performed on EDTA and citrate. Ann Biol Clin (Paris). 2017;75(1):61-6. 
11. Greinacher A, Selleng K. Thrombocytopenia in the intensive care unit patient. Hematology Am Soc Hematol Educ Program. 2010;2010:135-43.

12. Thachil J, Warkentin TE. How do we approach thrombocytopenia in critically ill patients? Br J Haematol. 2017;177(1):27-38.

13. Brown RS Jr. Current management of thrombocytopenia in chronic liver disease. Gastroenterol Hepatol (N Y). 2019;15(3):155-7.

14. Thiolliere F, Serre-Sapin AF, Reignier J, Benedit M, Constantin JM, Lebert C, et al. Epidemiology and outcome of thrombocytopenic patients in the intensive care unit: results of a prospective multicenter study. Intensive Care Med. 2013;39(8):1460-8.

15. Antier N, Quenot JP, Doise JM, Noel R, Demaistre E, Devilliers H. Mechanisms and etiologies of thrombocytopenia in the intensive care unit: impact of extensive investigations. Ann Intensive Care. 2014;4:24.

16. Selleng S, Malowsky B, Strobel U, Wessel A, Ittermann T, Wollert HG, et al. Early-onset and persisting thrombocytopenia in post-cardiac surgery patients is rarely due to heparin-induced thrombocytopenia, even when antibody tests are positive. J Thromb Haemost. 2010;8(1):30-6.

17. Nijsten MW, ten Duis HJ, Zijlstra JG, Porte RJ, Zwaveling JH, Paling JC, et al. Blunted rise in platelet count in critically ill patients is associated with worse outcome. Crit Care Med. 2000;28(12):3843-6.

18. Kaushansky K. Determinants of platelet number and regulation of thrombopoiesis. Hematology Am Soc Hematol Educ Program. 2009;2009(1):147-52.

19. Stansbury LG, Hess AS, Thompson K, Kramer B, Scalea TM, Hess JR. The clinical significance of platelet counts in the first 24 hours after severe injury. Transfusion. 2013;53(4):783-9.

20. Venkata C, Kashyap R, Farmer JC, Afessa B. Thrombocytopenia in adult patients with sepsis: incidence, risk factors, and its association with clinical outcome. J Intensive Care. 2013;1(1):9.

21. Crowther MA, Cook DJ, Albert M, Williamson D, Meade M, Granton J, et al. The 4Ts scoring system for heparin-induced thrombocytopenia in medicalsurgical intensive care unit patients. J Crit Care. 2010;25(2):287-93.

22. Vandijck DM, Blot SI, De Waele JJ, Hoste EA, Vandewoude KH, Decruyenaere JM. Thrombocytopenia and outcome in critically ill patients with bloodstream infection. Heart Lung. 2010;39(1):21-6.

23. Akca S, Haji-Michael $P$, de Mendonça A, Suter P, Levi M, Vincent JL. Time course of platelet counts in critically ill patients. Crit Care Med. 2002;30(4):753-6.

24. Moreau D, Timsit JF, Vesin A, Garrouste-Orgeas M, de Lassence A, Zahar JR, et al. Platelet count decline: an early prognostic marker in critically ill patients with prolonged ICU stays. Chest. 2007;131(6):1735-41.

25. Lee EJ, Lee Al. Thrombocytopenia. Prim Care. 2016;43(4):543-57.

26. Greenberg EM, Kaled ES. Thrombocytopenia. Crit Care Nurs Clin North Am. 2013:25(4):427-34

27. Shi ZH, Ding HJ. Etiology and diagnosis and treatment strategy of pregnancy with thrombocytopenia. J Pract Obstetrics Gynecol. 2016;32(9): 649-52.

28. Limper M, de Leeuw K, Lely AT, Westerink J, Teng YKO, Eikenboom J, et al. Diagnosing and treating antiphospholipid syndrome: a consensus paper. Neth J Med. 2019;77(3):98-108.

29. Levi M, Scully M, Singer M. The role of ADAMTS-13 in the coagulopathy of sepsis. J Thromb Haemost. 2018;16(4):646-51.

30. Laffan MA, Lester W, O'Donnell JS, Will A, Tait RC, Goodeve A, et al. The diagnosis and management of von Willebrand disease: a United Kingdom haemophilia Centre doctors organization guideline approved by the British Committee for Standards in haematology. Br J Haematol. 2014;167(4):453-65.

31. Thrombus prevention and treatment Committee of cardiovascular physicians branch of Chinese Medical Association, editorial board of Chinese Medical Journal. Expert consensus on heparin induced thrombocytopenia in China (2017). Chin Med J. 2018;98(6):408-17.

32. Van der Linden T, Souweine B, Dupic L, Soufir L, Meyer P. Management of thrombocytopenia in the ICU (pregnancy excluded). Ann Intensive Care. 2012;2(1):42

33. Chinese Expert Federation of Hemophagocytic Syndrome, Hematology Group of Pediatric Branch of Chinese Medical Association. Consensus of Chinese experts on diagnosis and treatment of hemophagocytic syndrome. Chin Med J. 2018;98(2):91-5.

34. Moreno A, Menke D. Assessment of platelet numbers and morphology in the peripheral blood smear. Clin Lab Med. 2002;22(1):193-213 vii.

35. De Silva NL, Sivayoganathan S, Sivashangar A, Wickramasinghe W, Gooneratne L, Rajapakse S. Can findings on peripheral blood smear differentiate leptospirosis from other infections? A preliminary comparative study. Trans R Soc Trop Med Hyg. 2018;112(2):94-6.

36. Afkhami M, Vergara-Lluri M, Brynes RK, Siddiqi IN. Peripheral blood smears, bone marrow aspiration, trephine and clot biopsies: methods and protocols. Methods Mol Biol. 2014;1180:257-69.

37. Wongrakpanich S, Salahuddin M, Mittar P. An abnormal peripheral blood smear and altered mental status. Cleve Clin J Med. 2016;83(9):643-4.

38. Iba T, Levy JH, Wada H, Thachil J, Warkentin TE, Levi M, et al. Differential diagnoses for sepsis-induced disseminated intravascular coagulation: communication from the SSC of the ISTH. J Thromb Haemost. 2019;17(2):415-9.

39. Iba T, Umemura Y, Watanabe E, Wada T, Hayashida K, Kushimoto S, et al. Diagnosis of sepsis-induced disseminated intravascular coagulation and coagulopathy. Acute Med Surg. 2019;6(3):223-32.

40. Scully M, Cataland S, Coppo P, de la Rubia J, Friedman KD, Kremer Hovinga $J$, et al. Consensus on the standardization of terminology in thrombotic thrombocytopenic purpura and related thrombotic microangiopathies. J Thromb Haemost. 2017;15(2):312-22

41. Thomas W, Cutler JA, Moore GW, McDonald V, Hunt BJ. The utility of a fast turnaround ADAMTS13 activity in the diagnosis and exclusion of thrombotic thrombocytopenic purpura. Br J Haematol. 2019;184(6):1026-32.

42. Ono T, Mimuro J, Madoiwa S, Soejima K, Kashiwakura Y, Ishiwata A, et al. Severe secondary deficiency of von Willebrand factor-cleaving protease (ADAMTS13) in patients with sepsis-induced disseminated intravascular coagulation: its correlation with development of renal failure. Blood. 2006; 107(2):528-34

43. Azoulay E, Knoebl P, Garnacho-Montero J, Rusinova K, Galstian G, Eggimann $P$, et al. Expert statements on the standard of care in critically ill adult patients with atypical hemolytic uremic syndrome. Chest. 2017;152(2):424-34.

44. Mendonca R, Silveira AA, Conran N. Red cell DAMPs and inflammation. Inflamm Res. 2016;65(9):665-78.

45. Iba T, Levy JH. Inflammation and thrombosis: roles of neutrophils, platelets and endothelial cells and their interactions in thrombus formation during sepsis. J Thromb Haemost. 2018;16(2):231-41.

46. Noris M, Mescia F, Remuzzi G. STEC-HUS, atypical HUS and TTP are all diseases of complement activation. Nat Rev Nephrol. 2012;8(11):622-33.

47. Hulstein JJ, van Runnard Heimel PJ, Franx A, Lenting PJ, Bruinse HW, Silence $\mathrm{K}$, et al. Acute activation of the endothelium results in increased levels of active von Willebrand factor in hemolysis, elevated liver enzymes and low platelets (HELLP) syndrome. J Thromb Haemost. 2006;4(12):2569-75.

48. Hunt BJ, Thomas-Dewing RR, Bramham K, Lucas SB. Preventing maternal deaths due to acquired thrombotic thrombocytopenic purpura. J Obstet Gynaecol Res. 2013;39(1):347-50.

49. Warkentin TE. Clinical picture of heparin-induced thrombocytopenia (HIT) and its differentiation from non-HIT thrombocytopenia. Thromb Haemost. 2016;116(5):813-22.

50. Warkentin TE, Greinacher A, Gruel Y, Aster RH, Chong BH. Scientfic and standardization Committee of the International Society on thrombosis and haemostasis. Laboratory testing for heparin-induced thrombocytopenia: a conceptual framework and implications for diagnosis. J Thromb Haemost. 2011;9(12):2498-500.

51. Cuker A, Arepally GM, Chong BH, Cines DB, Greinacher A, Gruel Y, et al. American Society of Hematology 2018 guidelines for management of venous thromboembolism: heparin-induced thrombocytopenia. Blood Adv. 2018;2(22):3360-92

52. Iba T, Watanabe E, Umemura Y, Wada T, Hayashida K, Kushimoto S, et al Sepsis-associated disseminated intravascular coagulation and its differential diagnoses. J Intensive Care. 2019;7:32.

53. Warkentin TE. Ischemic limb gangrene with pulses. N Engl J Med. 2015; 373(7):642-55

54. Garcia D, Erkan D. Diagnosis and Management of the Antiphospholipid Syndrome. N Engl J Med. 2018;378(21):2010-21.

55. Shruti Chaturvedi, Keith R McCrae. Diagnosis and management of the antiphospholipid syndrome. Blood Rev2017; 31(6): 406-417.

56. Parker CJ. Update on the diagnosis and management of paroxysmal nocturnal hemoglobinuria. Hematology Am Soc Hematol Educ Program. 2016;2016(1):208-16

57. Ranucci M, Baryshnikova E. For the surgical and clinical outcome research score group. The interaction between preoperative platelet count and function and its relationship with postoperative bleeding in cardiac surgery. Platelets. 2017;28(8):794-8. 
58. Björklund E, Hansson EC, Romlin BS, Jeppsson A, Malm CJ. Postoperative platelet function is associated with severe bleeding in ticagrelor-treated patients. Interact Cardiovasc Thorac Surg. 2019;28(5):709-15.

59. Khalaf Adeli E, Mostafa Alavi S, Alizadeh-Ghavidel A, Bakhshandeh-Abkenar $\mathrm{H}$, Pourfathollah AA. Perioperative changes in platelet count and function in patients undergoing cardiac surgery. Med J Islam Repub Iran. 2017:31:37.

60. McEwen BJ. The influence of herbal medicine on platelet function and coagulation: a narrative review. Semin Thromb Hemost. 2015;41(3):300-14.

61. Lundahl TH, Petersson J, Fagerberg $H$, Berg S, Lindahl TL. Impaired platelet function correlates with multi-organ dysfunction. A study of patients with sepsis. Platelets. 1998;9(3-4):223-5.

62. Yaguchi A, Lobo FL, Vincent $J$, Pradier O. Platelet function in sepsis. J Thromb Haemost. 2004;2(12):2096-102.

63. Zhong LC, Song JC, Zeng QB, Lin QW, Hu YJ, Song XM. Coagulation dysfunction in different phases of bloodstream infection-induced sepsis: a clinical study. J Med Postgrad. 2019;32(1):43-7

64. Wohlauer MV, Moore EE, Thomas S, Sauaia A, Evans E, Harr J, et al. Early platelet dysfunction: an unrecognized role in the acute coagulopathy of trauma. J Am Coll Surg. 2012;214(5):739-46.

65. ZENG QB, SONG JC, YANG Y, Lin QW, Xu J, Hu YJ, et al. The clinical value of platelet function changes in trauma patients for prognosis judgment. J Med Postgraduates. 2019;32(8):845-9.

66. Davis PK, Musunuru H, Walsh M, Cassady R, Yount R, Losiniecki $A$, et al. Platelet dysfunction is an early marker for traumatic brain injury-induced coagulopathy. Neurocrit Care. 2013;18(2):201-8.

67. Harder S, Klinkhardt U, Alvarez JM. Avoidance of bleeding during surgery in patients receiving anticoagulant and/or antiplatelet therapy: pharmacokinetic and pharmacodynamic considerations. Clin Pharmacokinet. 2004;43(14):963-81.

68. Joseph B, Pandit V, Sadoun M, Larkins CG, Kulvatunyou N, Tang A, et al. A prospective evaluation of platelet function in patients on antiplatelet therapy with traumatic intracranial hemorrhage. J Trauma Acute Care Surg. 2013;75(6):990-4

69. Just Vinholt P, Højrup Knudsen G, Sperling S, Frederiksen H, Nielsen C. Platelet function tests predict bleeding in patients with acute myeloid leukemia and thrombocytopenia. Am J Hematol. 2019:94(8):891-901.

70. Zarychanski R, Houston DS. Assessing thrombocytopenia in the intensive care unit: the past, present, and future. Hematology Am Soc Hematol Educ Program. 2017;2017(1):660-6.

71. Israels SJ. Laboratory testing for platelet function disorders. Int J Lab Hematol. 2015;37(Suppl 1):18-24.

72. Vinholt PJ, Hvas AM, Nybo M. An overview of platelet indices and methods for evaluating platelet function in thrombocytopenic patients. Eur J Haematol. 2014;92(5):367-76.

73. Wan P, Yu M, Qian M, Tong H, Su L. Sonoclot coagulation analysis: a useful tool to predict mortality in overt disseminated intravascular coagulation. Blood Coagul Fibrinolysis. 2016;27(1):77-83.

74. Konkle BA. Acquired disorders of platelet function. Hematology Am Soc Hematol Educ Program. 2011;2011:391-6.

75. Whiting P, Al M, Westwood M, Ramos IC, Ryder S, Armstrong N, et al. Viscoelastic point-of-care testing to assist with the diagnosis, management and monitoring of haemostasis: a systematic review and cost-effectiveness analysis. Health Technol Assess. 2015;19(58):1-228 v-vi.

76. Bhardwaj V, Malhotra P, Hasija S, Chowdury UK, Pangasa N. Coagulopathies in cyanotic cardiac patients: an analysis with three point - of - care testing devices (Thromboelastography, rotational thromboelastometry, and sonoclot analyzer). Ann Card Anaesth. 2017;20(2):212-8.

77. Liu HQ, Zeng QB, Song JC, Yang Y, Zhong LC, Yu T, et al. A comparative study of thromboelastography and Centuryclot coagulation analyzer in monitoring coagulation function in intensive care patients. Clin J Med Offic. 2019;47(4):387-9.

78. Skipper MT, Rubak P, Stentoft J, Hvas AM, Larsen OH. Evaluation of platelet function in thrombocytopenia. Platelets. 2018;29(3):270-6.

79. Bakchoul T, Marini I. Drug-associated thrombocytopenia. Hematology Am Soc Hematol Educ Program. 2018;2018(1):576-83.

80. Larkin CM, Santos-Martinez MJ, Ryan T, Radomski MW. Sepsis-associated thrombocytopenia. Thromb Res. 2016;141:11-6.

81. Lawson JW, Kitchens CS. Surgery and hemostasis. Curr Opin Hematol. 2015; 22(5):420-7.

82. Puavilai T, Thadanipon $K$, Rattanasiri S, Ingsathit A, McEvoy M, Attia J. et al. Treatment efficacy for adult persistent immune thrombocytopenia: a systematic review and network meta-analysis. Br J Haematol. 2020;188(3): 450-9.

83. Koeltz A, Gendron N, Ajzenberg N, Longrois D. How to manage thrombocytopenia with ECLS: a proposal of clinical reasoning tools. J Extra Corpor Technol. 2018;50(4):256-9.

84. Devalia V, Hamilton MS, Molloy AM. British Committee for Standards in haematology. Guidelines for the diagnosis and treatment of cobalamin and folate disorders. Br J Haematol. 2014;166(4):496-513.

85. Corcoran TB, O'Neill MA, Webb SA, Ho KM. Prevalence of vitamin deficiencies on admission: relationship to hospital mortality in critically ill patients. Anaesth Intensive Care. 2009;37(2):254-60.

86. Kamel AY, Dave NJ, Zhao VM, Griffith DP, Connor MJ Jr, Ziegler TR. Micronutrient alterations during continuous renal replacement therapy in critically ill adults: a retrospective study. Nutr Clin Pract. 2018;33(3):439-46.

87. Rodeghiero F, Carli G. Beyond immune thrombocytopenia: the evolving role of thrombopoietin receptor agonists. Ann Hematol. 2017;96(9):1421-34.

88. Al-Samkari H, Kuter DJ. Optimal use of thrombopoietin receptor agonists in immune thrombocytopenia. Ther Adv Hematol. 2019;10:2040620719841735.

89. Thrombosis and Hemostasis Group, Hematology Society, Chinese Medical Association. Consensus of Chinese experts on diagnosis and treatment of adult primary immune thrombocytopenia(version 2016). Chin J Hematol. 2016;37(2):89-93.

90. Dahal S, Upadhyay S, Banjade R, Dhakal P, Khanal N, Bhatt VR. Thrombocytopenia in patients with chronic hepatitis $C$ virus infection. Mediterr J Hematol Infect Dis. 2017;9(1):e2017019.

91. Maan R, de Knegt RJ, Veldt BJ. Management of thrombocytopenia in chronic liver disease: focus on pharmacotherapeutic strategies. Drugs. 2015; 75(17):1981-92.

92. Wu Q, Ren JN, Wu XW, Wang GF, Gu GS, Liu S, et al. Recombinant human thrombopoietin improves platelet counts and reduces platelet transfusion possibility among patients with severe sepsis and thrombocytopenia: a prospective study. J Crit Care. 2014;29(3):362-6.

93. Cuccurullo A, Greco E, Lupia E, De Giuli P, Bosco O, Martin-Conte E, et al. Blockade of Thrombopoietin reduces organ damage in experimental Endotoxemia and Polymicrobial Sepsis. PLoS One. 2016;11(3):e0151088.

94. Schwertschlag US, Trepicchio WL, Dykstra KH, Keith JC, Turner KJ, Dorner AJ. Hematopoietic, immunomodulatory and epithelial effects of interleukin-11. Leukemia. 1999;13(9):1307-15.

95. Dorner AJ, Goldman SJ, Keith JC Jr. Interleukin-11. BioDrugs. 1997;8(6):418-29.

96. Vadhan-Raj S. Management of chemotherapy-induced thrombocytopenia: current status of thrombopoietic agents. Semin Hematol. 2009;46(1 Suppl 2):S26-32.

97. Wu XF, Wang $\sqcup$, Sun L, Li TT, Ran XH. Analysis of clinical effects and mechanism of recombinant human interleukin-11 with glucocorticoids for treatment of idiopathic thrombocytopenic purpura. Exp Ther Med. 2017;13(2):519-22.

98. Fontana V, Dudkiewicz P, Jy W, Horstman L, Ahn YS. Interleukin-11 for treatment of hepatitis C-associated ITP. Acta Haematol. 2008;119(2):126-32.

99. Harter K, Levine M, Henderson SO. Anticoagulation drug therapy: a review. West J Emerg Med. 2015;16(1):11-7.

100. Linnemann B. Antiphospholipid syndrome - an update. Vasa. 2018:47(6):451-64.

101. Cervera R, Rodríguez-Pintó I, Espinosa G. The diagnosis and clinical management of the catastrophic antiphospholipid syndrome: a comprehensive review. J Autoimmun. 2018;92:1-11.

102. Fathi M. Heparin-induced thrombocytopenia (HIT): identification and treatment pathways. Glob Cardiol Sci Pract. 2018;2018(2):15.

103. Skelley JW, Kyle JA, Roberts RA. Novel oral anticoagulants for heparininduced thrombocytopenia. J Thromb Thrombolysis. 2016;42(2):172-8.

104. Li X, Ma XC. The role of heparin in sepsis: much more than just an anticoagulant. Br J Haematol. 2017;179(3):389-8.

105. Meziani F, Gando S, Vincent JL. Should all patients with sepsis receive anticoagulation? Yes Intensive Care Med. 2017;43(3):452-4

106. Zarychanski R, Abou-Setta AM, Kanji S, Turgeon AF, Kumar A, Houston DS. et al.the efficacy and safety of heparin in patients with sepsis: a systematic review and meta analysis. Crit Care Med. 2015;43(3):511-8.

107. Iba T, Levy JH, Raj A, Warkentin TE. Advance in the Management of SepsisInduced Coagulopathy and Disseminated Intravascular Coagulation. J Clin Med. 2019;8(5):728. https://doi.org/10.3390/jcm8050728.

108. Scully M, Levi M. How we manage haemostasis during sepsis. $\mathrm{Br} J$ Haematol. 2019:185(2):209-18.

109. Abraham E, Reinhart K, Opal S, Demeyer I, Doig C, Rodriguez AL, et al. Efficacy and safety of tifacogin (recombinant tissue factor pathway inhibitor) in severe sepsis: a randomized controlled trial. JAMA. 2003;290(2):238-47. 
110. Vincent $J$, Francois B, Zabolotskikh I, Daga MK, Lascarrou JB, Kirov MY, et al. Effect of a recombinant human soluble Thrombomodulin on mortality in patients with Sepsis-associated coagulopathy: the SCARLET randomized clinical trial. JAMA. 2019;321(20):1993-2002.

111. Ranieri VM, Thompson BT, Barie PS, Dhainaut JF, Douglas IS, Finfer S, et al. Drotrecogin alfa (activated) in adults with septic shock. N Engl J Med. 2012; 366(22):2055-64

112. Liu SY, Song JC, Mao HD, Zhao JB, Song Q. Expert consensus on diagnosis and treatment of heat radiation diseases in China. Med J Chin PLA. 2019; 44(3):181-96.

113. Lim HY, Leung P, Manitta V, Nandurkar H, Ho P. A comparison of global coagulation assays between normal controls and patients with thrombocytopenia. Int J Lab Hematol. 2019;41(2):184-91.

114. Karhausen JA, Smeltz AM, Akushevich I, Cooter M, Podgoreanu MV, StaffordSmith $\mathrm{M}$, et al. Platelet counts and postoperative stroke after coronary artery bypass grafting surgery. Anesth Analg. 2017;125(4):1129-39.

115. Myles PS, Smith JA, Forbes A, Silbert B, Jayarajah M, Painter T, et al. Stopping vs. continuing aspirin before coronary artery surgery. N Engl J Med. 2016;374(8):728-37.

116. Saw J, Wong GC, Mayo J, Bernstein V, Mancini GB, Ye J, et al. Ticagrelor and aspirin for the prevention of cardiovascular events after coronary artery bypass graft surgery. Heart. 2016;102(10):763-9.

117. Raso Vasquez AO, Kertai MD, Fontes ML. Postoperative thrombocytopenia: why you should consider antiplatelet therapy? Curr Opin Anaesthesiol. 2018; 31(1):61-6.

118. McCarthy CP, Steg G, Bhatt DL. The management of antiplatelet therapy in acute coronary syndrome patients with thrombocytopenia: a clinical conundrum. Eur Heart J. 2017:38(47):3488-92.

119. Morici N, Cantoni S, Vallerio P, Cattaneo M, Savonitto S. Antiplatelet and anticoagulation treatment in patients with thrombocytopenia. Curr Pharm Des. 2017;23(9):1354-65.

120. Franchini M, Mannucci PM. Primary hyperfibrinolysis: facts and fancies. Thromb Res. 2018;166:71-5.

121. Roberts I. Tranexamic acid in trauma: how should we use it? J Thromb Haemost. 2015;13(Suppl 1):S195-9.

122. Khan M, Jehan F, Bulger EM, O'Keeffe T, Holcomb JB, Wade CE, et al. Severely injured trauma patients with admission hyperfibrinolysis: is there a role of tranexamic acid? Findings from the PROPPR trial. J Trauma Acute Care Surg 2018;85(5):851-857.

123. Eghbali A, Melikof $L$, Taherahmadi $H$, Bagheri B. Efficacy of tranexamic acid for the prevention of bleeding in patients with von Willebrand disease and Glanzmann thrombasthenia: a controlled, before and after trial. Haemophilia. 2016;22(5):e423-6.

124. Mohri $\mathrm{H}$. High dose of tranexamic acid for treatment of severe menorrhagia in patients with von Willebrand disease. J Thromb Thrombolysis. 2002;14(3): 255-7.

125. Gordz S, Mrowietz C, Pindur G, Park JW, Jung F. Effect of desmopressin (DDAVP) on platelet membrane glycoprotein expression in patients with von Willebrand's disease. Clin Hemorheol Microcirc. 2005;32(2):83-7.

126. Calmer S, Ferkau A, Larmann J, Johanning K, Czaja E, Hagl C, et al. Desmopressin (DDAVP) improves recruitment of activated platelets to collagen but simultaneously increases platelet endothelial interactions in vitro. Platelets. 2014;25(1):8-15.

127. Leissinger C, Carcao M, Gill JC, Journeycake J, Singleton T, Valentino L. Desmopressin (DDAVP) in the management of patients bleeding disorders. Haemophilia. 2014;20(2):158-67.

128. Mannucci PM, Remuzzi G, Pusineri F, Lombardi R, Valsecchi C, Mecca G, et al. Deamino-8-D-arginine vasopressin shortens the bleeding time in uremia. N Engl J Med. 1983;308(1):8-12.

129. Teng R, Mitchell PD, Butler K. The effect of desmopressin on bleeding time and platelet aggregation in healthy volunteers administered ticagrelor. $J$ Clin Pharm Ther. 2014;39(2):186-91.

130. Flordal PA, Sahlin S. Use of desmopressin to prevent bleeding complications in patients treated with aspirin. Br J Surg. 1993;80(6):723-4

131. Keyl C, Kmitta E, Kueri S, Zietak T, Trenk D. Effects of aspirin and desmopressin on platelet reactivity in patients undergoing cardiac surgery with extracorporeal circulation. Thromb Haemost. 2011;105(1): $113-21$

132. Wademan BH, Galvin SD. Desmopressin for reducing postoperative blood loss and transfusion requirements following cardiac surgery in adults. Interact Cardiovasc Thorac Surg. 2014;18(3):360-70.
133. Jin L, Ji HW. Effect of desmopressin on platelet aggregation and blood loss in patients undergoing valvular heart surgery. Chin Med J (Engl). 2015; 128(5):644-7.

134. Van Herzeele C, De Bruyne P, Evans J, Eggert P, Lottmann H, Norgaard JP, et al. Safety profile of desmopressin tablet for enuresis in a prospective study. Adv Ther. 2014;31(12):1306-16.

135. Singleton T, Kruse-Jarres R, Leissinger C. Emergency department care for patients with hemophilia and von Willebrand disease. J Emerg Med. 2010; 39(2):158-65.

136. Mauz-Körholz C, Budde U, Kruck H, Körholz D, Göbel U. Management of severe chronic thrombocytopenia in von Willebrand's disease type 2B. Arch Dis Child. 1998;78(3):257-60.

137. Kistangari G, McCrae KR. Immune thrombocytopenia. Hematol Oncol Clin North Am. 2013;27(3):495-520.

138. Kremer Hovinga JA, Coppo P, Lämmle B, Moake JL, Miyata T, Vanhoorelbeke K. Thrombotic thrombocytopenic purpura. Nat Rev Dis Primers. 2017;3:17020.

139. Cervera R, Rodriguez-Pinto I, Colafrancesco S, Conti F, Valesini G, Rosário C, et al. 14th international congress on antiphospholipid antibodies task force report on catastrophic antiphospholipid syndrome. Autoimmun Rev. 2014: 13(7):699-707

140. Lambert MP, Gernsheimer TB. Clinical updates in adult immune thrombocytopenia. Blood. 2017;129(21):2829-35.

141. Balduini CL, Gugliotta L, Luppi M, Laurenti L, Klersy C, Pieresca C, et al. High versus standard dose methylprednisolone in the acute phase of idiopathic thrombotic thrombocytopenic purpura: a randomized study. Ann Hematol. 2010;89(6):591-6.

142. Azoulay E, Bauer PR, Mariotte E, Russell L, Knoebl P, Martin-Loeches I, et al. Expert statement on the ICU management of patients with thrombotic thrombocytopenic purpura. Intensive Care Med. 2019;45(11):1518-39.

143. Stasi R, Brunetti M, Pagano A, Stipa E, Masi M, Amadori S. Pulsed intravenous high-dose dexamethasone in adults with chronic idiopathic thrombocytopenic purpura. Blood Cells Mol Dis. 2000;26(6):582-6.

144. Mithoowani S, Gregory-Miller K, Goy J, Miller MC, Wang G, Noroozi N, et al. High-dose dexamethasone compared with prednisone for previously untreated primary immune thrombocytopenia: a systematic review and meta-analysis. Lancet Haematol. 2016:3(10):e489-96.

145. Kuemmerle-Deschner JB. CAPS-pathogenesis, presentation and treatment of an autoinflammatory disease. Semin Immunopathol. 2015;37(4):377-85.

146. Witkowski M, Witkowska M, Robak T. Autoimmune thrombocytopenia: current treatment options in adults with a focus on novel drugs. Eur J Haematol. 2019:103(6):531-41.

147. Lo E, Deane S. Diagnosis and classification of immune-mediated thrombocytopenia. Autoimmun Rev. 2014;13(4-5):577-83.

148. Anderson D, Ali K, Blanchette V, Brouwers M, Couban S, Radmoor P. et al. Guidelines on the use of intravenous immune globulin for hematologic conditions. Transfus Med Rev. 2007;21(2 Suppl 1):S9-56.

149. Kazzaz NM, McCune WJ, Knight JS. Treatment of catastrophic antiphospholipid syndrome. Curr Opin Rheumatol. 2016;28(3):218-27.

150. George JN, Aster RH. Drug-induced thrombocytopenia: pathogenesis, evaluation, and management. Hematology Am Soc Hematol Educ Program. 2009:2009(1):153-8.

151. Rhodes A, Evans LE, Alhazzani W, Levy MM, Antonelli M, Ferrer R, et al. Surviving sepsis campaign: international guidelines for management of sepsis and septic shock: 2016. Intensive Care Med. 2017;43(3):304-77.

152. Mohanty E, Nazir S, Sheppard Jl, Forman DA, Warkentin TE. High-dose intravenous immunoglobulin to treat spontaneous heparin-induced thrombocytopenia syndrome. J Thromb Haemost. 2019:17(5):841-4.

153. Irani M, Siegal E, Jella A, Aster R, Padmanabhan A. Use of intravenous immunoglobulin $\mathrm{G}$ to treat spontaneous heparin-induced thrombocytopenia. Transfusion. 2019:59(3):931-4.

154. Park BD, Kumar M, Nagalla S, De Simone N, Aster RH, Padmanabhan A, et al. Intravenous immunoglobulin as an adjunct therapy in persisting heparininduced thrombocytopenia. Transfus Apher Sci. 2018;57(4):561-5.

155. Hill A, Hill QA. Autoimmune hemolytic anemia. Hematology Am Soc Hematol Educ Program. 2018;2018(1):382-9.

156. Al-Samkari H, Berliner N. Hemophagocytic Lymphohistiocytosis. Annu Rev Pathol. 2018;13:27-49

157. National Health Commission of the PRC. Transfusion of whole blood and blood components: WS / T 623-2018 [S], 2018.

158. Estcourt LJ, Birchall J, Allard S, Bassey SJ, Hersey P, Kerr JP, et al. Guidelines for the use of platelet transfusions. Br J Haematol. 2017;176(3):365-94. 
159. Kaufman RM, Djulbegovic B, Gernsheimer T, Kleinman S, Tinmouth AT, Capocelli KE, et al. Platelet transfusion: a clinical practice guideline from the AABB. Ann Intern Med. 2015;162(3):205-13.

160. Yuan Q, Sun YR, Wu X, Yu J, Li ZQ, Du ZY, et al. Coagulopathy in traumatic brain injury and its correlation with progressive hemorrhagic injury: a systematic review and meta-analysis. J Neurotrauma. 2016;33(14):1279-91.

161. Conti A, Renzi N, Molesti D, Bianchi S, Bogazzi I, Bongini G, et al. Short and long-term mortality of patients presenting with bleeding events to the emergency department. Am J Emerg Med. 2017;35(12):1867-72.

162. Ott MM, Eriksson E, Vanderkolk W, Christianson D, Davis A, Scholten D. Antiplatelet and anticoagulation therapies do not increase mortality in the absence of traumatic brain injury. J Trauma. 2010;68(3):560-3.

163. Ohmori T, Kitamura T, Onishi H, Ishihara J, Nojima T, Yamamoto K. Effect of pre-injury anticoagulant and antiplatelet agents on blood loss in elderly patients with severe trauma. Acute Med Surg. 2016;3(2):114-9.

164. Coleman J, Baldawi M, Heidt D. The effect anticoagulation status on geriatric fall trauma patients. Am J Surg. 2016;212(6):1237-42

165. Hansson EC, Shams Hakimi C, Astrom-Olsson K, Hesse C, Wallén H, Dellborg $M$, et al. Effects of ex vivo platelet supplementation on platelet aggregability in blood samples from patients treated with acetylsalicylic acid, clopidogrel, or ticagrelor. Br J Anaesth. 2014;112(3):570-5.

166. Martin AC, Berndt C, Calmette L, Philip I, Decouture B, Gaussem P, et al. The effectiveness of platelet supplementation for the reversal of ticagrelorinduced inhibition of platelet aggregation: an in-vitro study. Eur J Anaesthesiol. 2016;33(5):361-7.

167. Frontera JA, Lewin JJ 3rd, Rabinstein AA, Aisiku IP, Alexandrov AW, Cook AM, et al. Guideline for reversal of antithrombotics in intracranial hemorrhage: a statement for healthcare professionals from the neurocritical care society and society of critical care medicine. Neurocrit Care. 2016;24(1):6-46.

168. Blumberg N, Cholette JM, Schmidt AE, Phipps RP, Spinelli SL, Heal JM, et al. Management of platelet disorders and platelet transfusions in ICU patients. Transfus Med Rev. 2017;31(4):252-7

169. Newland A, Bentley R, Jakubowska A, Liebman H, Lorens J, Peck-Radosavljevic M. et al.a systematic literature review on the use of platelet transfusions in patients with thrombocytopenia. Hematology. 2019;24(1):679-719.

170. Lippi G, Favaloro EJ, Buoro S. Platelet transfusion thresholds: How low can we go in respect to platelet counting? Semin Thromb Hemost. 2019. https://doi.org/10.1055/s-0039-1696943.

171. Stettler GR, Sumislawski JJ, Moore EE, Nunns GR, Kornblith LZ, Conroy AS, et al. Citrated kaolin thrombelastography (TEG) thresholds for goal-directed therapy in injured patients receiving massive transfusion. J Trauma Acute Care Surg. 2018;85(4):734-40

172. Zhou H, Chen L, He HT. Intraoperative and postoperative effects of TEGguided platelet transfusion on antiplatelet drug-related intracerebral hemorrhage patients. Exp Ther Med. 2019;17(3):2263-7.

173. Zeng QB, Song JC, Hu W, Shang F, Lin QW, Zhong LC, et al. Clinical study of thromboelastography in the indication of platelet transfusion in severe trauma. Chin J Transfus. 2019;32(10):1004-7.

174. Fu QH, Wang J. Expert consensus on platelet transfusion with different $A B O$ blood types in emergency. Chin J Blood Transfus. 2017;30(07):666-7.

175. Nahirniak S, Slichter SJ, Tanael S, Rebulla P, Pavenski K, Vassallo R, et al. Guidance on platelet transfusion for patients with hypoproliferative thrombocytopenia. Transfus Med Rev. 2015;29(1):3-13.

176. Valsami S, Dimitroulis D, Gialeraki A, Chimonidou M, Politou M. Current trends in platelet transfusions practice: the role of $\mathrm{ABO}-\mathrm{RhD}$ and human leukocyte antigen incompatibility. Asian J Transfus Sci. 2015;9(2):117-23.

177. Hod E, Schwartz J. Platelet transfusion refractoriness. Br J Haematol. 2008; 142(3):348-60

178. Stanworth SJ, Navarrete C, Estcourt LMarsh J. Platelet refractoriness-practical approaches and ongoing dilemmas in patient management. Br J Haematol. 2015;171(3):297-305.

179. Schmidt AE, Refaai MA, Coppage M. HLA-mediated platelet refractoriness. Am J Clin Pathol. 2019;151(4):353-63.

180. Juskewitch JE, Norgan AP, De Goey SR, Duellman PM, Wakefield LL, Gandhi MJ, et al. How do I manage the platelet transfusion-refractory patient? Transfusion. 2017:57(12):2828-35.

181. Meinke S, Karlström C, Höglund P. Complement as an immune barrier in platelet transfusion refractoriness. Transfus Med Rev. 2019;33(4):231-5.

182. Schwartz J, Padmanabhan A, Aqui N, Balogun RA, Connelly-Smith L, Delaney M. et al.Guidelines on the use of therapeutic apheresis in clinical practice-evidence-based approach from the writing Committee of the American Society for apheresis: the seventh special issue. J Clin Apher. 2016; 31(3):149-62.

183. Winters JL. Plasma exchange in thrombotic microangiopathies (TMAs) other than thrombotic thrombocytopenic purpura (TTP). Hematology Am Soc Hematol Educ Program. 2017;2017(1):632-8.

184. Adamski J. Thrombotic microangiopathy and indications for therapeutic plasma exchange. Hematology Am Soc Hematol Educ Program. 2014; 2014(1):444-9.

185. Scully M. Thrombocytopenia in hospitalized patients: approach to the patient with thrombotic microangiopathy. Hematology Am Soc Hematol Educ Program. 2017;2017(1):651-9.

186. Matsumoto M, Fujimura Y, Wada H, Kokame K, Miyakawa Y, Ueda Y, et al. Diagnostic and treatment guidelines for thrombotic thrombocytopenic purpura (TTP) 2017 in Japan. Int J Hematol. 2017;106(1):3-15.

187. Ramu B, Cogswell RJ, Reding MT, John R, Martin CM. Plasma exchange to remove heparin-induced thrombocytopenia antibodies and the use of heparin during cardiopulmonary bypass in critically ill cardiac patients. J Heart Lung Transplant. 2018;37(8):1038-40.

188. Onwuemene OA, Zantek ND, Rollins-Raval MA, Raval JS, Kiss JE, Ipe TS, et al. Therapeutic plasma exchange for management of heparin-induced thrombocytopenia: results of an international practice survey. J Clin Apher. 2019;34(5):545-54

189. Cho JH, Parilla M, Treml A, Wool GD. Plasma exchange for heparin-induced thrombocytopenia in patients on extracorporeal circuits: a challenging case and a survey of the field. J Clin Apher. 2019;34(1):64-72.

190. Thiery-Antier N, Binquet C, Vinault S, Meziani F, Boisramé-Helms J, Quenot JP. et al.is thrombocytopenia an early prognostic marker in septic shock? Crit Care Med. 2016;44(4):764-72.

191. Bedet A, Razazi K, Boissier F, Surenaud M, Hue S, Giraudier S, et al. Mechanisms of thrombocytopenia during septic shock: a multiplex cluster analysis of endogenous sepsis mediators. Shock. 2018;49(6):641-8.

192. Knaup H, Stahl K, Schmidt BMW, Idowu TO,Busch M,Wiesner O, et al.Early therapeutic plasma exchange in septic shock: a prospective open-label nonrandomized pilot study focusing on safety, hemodynamics, vascular barrier function, and biologic markers. Crit Care2018;22(1):285.

193. Putzu A, Schorer R, Lopez-Delgado JC, Cassina T, Landoni G. Blood purification and mortality in sepsis and septic shock: a systematic review and meta-analysis of randomized trials. Anesthesiology. 2019;131(3):580-93.

194. Hadem J, Hafer C, Schneider AS, Wiesner O, Beutel G, Fuehner T, et al. Therapeutic plasma exchange as rescue therapy in severe sepsis and septic shock: retrospective observational single-center study of 23 patients. BMC Anesthesiol. 2014;14:24.

195. Giudice V, Rosamilio R, Ferrara I, Seneca E, Serio B, Selleri C. Efficacy and safety of splenectomy in adult autoimmune hemolytic anemia. Open Med (Wars). 2016;11(1):374-80.

196. Agcaoglu O, Aksakal N, Tukenmez M, Cucuk O, Goksoy B, Bozbora A, et al. Is laparoscopic splenectomy safe in patients with immune thrombocytopenic purpura and very low platelet count? A single-institution experience. Ann Ital Chir. 2019;90:417-20

197. Ronco C, Ricci Z, Husain-Syed F. From multiple organ support therapy to extracorporeal organ support in critically ill patients. Blood Purif. 2019;48(2):99-105.

198. Oudemans-van Straaten HM. Hemostasis and thrombosis in continuous renal replacement treatment. Semin Thromb Hemost. 2015;41(1):91-8.

199. Akhoundi A, Singh B, Vela M, Chaudhary S, Monaghan M, Wilson GA, et al. Incidence of adverse events during continuous renal replacement therapy. Blood Purif. 2015;39(4):333-9.

200. Guru PK, Singh TD, Akhoundi A, Kashani KB. Association of thrombocytopenia and mortality in critically ill patients on continuous renal replacement therapy. Nephron. 2016;133(3):175-82.

201. Holmes CE, Huang JC, Cartelli C, Howard A, Rimmer J, Cushman M. The clinical diagnosis of heparin-induced thrombocytopenia in patients receiving continuous renal replacement therapy. J Thromb Thrombolysis. 2009:27(4):406-12

202. Choi JH, Luc JGY, Weber MP, Reddy HG, Maynes EJ, Deb AK. et al.Heparininduced thrombocytopenia during extracorporeal life support: incidence, management and outcomes. Ann Cardiothorac Surg. 2019;8(1):19-31.

203. Steiger T, Foltan M, Philipp A, Mueller T, Gruber M, Bredthauer A, et al. Accumulations of von Willebrand factor within ECMO oxygenators: Potential indicator of coagulation abnormalities in critically ill patients? Artif Organs. 2019;43(11):1065-76. 
204. Abrams D, Baldwin MR, Champion M, Agerstrand C, Eisenberger A, Bacchetta M. et al.Thrombocytopenia and extracorporeal membrane oxygenation in adults with acute respiratory failure: a cohort study. Intensive Care Med. 2016:42(5):844-52.

205. Vayne C, May MA, Bourguignon T, Lemoine E, Guery EA, Rollin J, et al. Frequency and clinical impact of platelet factor 4-specific antibodies in patients undergoing extracorporeal membrane oxygenation. Thromb Haemost. 2019;119(7):1138-46.

206. Hermann A, Schellongowski P, Bojic A, Robak O, Buchtele N, Staudinger T. ECMO without anticoagulation in patients with disease-related severe thrombocytopenia: feasible but futile? Artif Organs. 2019;43(11):1077-84.

Ready to submit your research? Choose BMC and benefit from:

- fast, convenient online submission

- thorough peer review by experienced researchers in your field

- rapid publication on acceptance

- support for research data, including large and complex data types

- gold Open Access which fosters wider collaboration and increased citations

- maximum visibility for your research: over $100 \mathrm{M}$ website views per year

At BMC, research is always in progress.

Learn more biomedcentral.com/submissions 